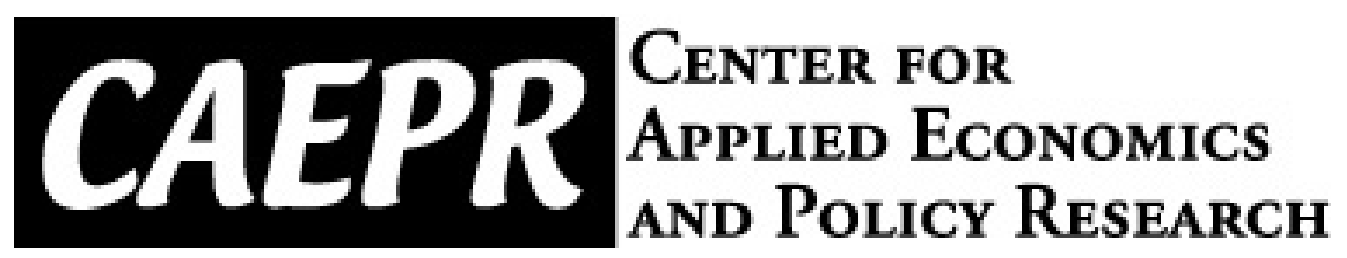

CAEPR Working Paper

\#007-2009

\title{
Policy Responses during the Depth of the 2007- 09 Financial Crisis: Instrument Innovations, Executive Reconfigurations, and Legacies for U.S. Governance
}

\author{
George M. von Furstenburg \\ Indiana University
}

June 1, 2009

This paper can be downloaded without charge from the Social Science Research Network electronic library at: http://ssrn.com/abstract=1416883.

The Center for Applied Economics and Policy Research resides in the Department of Economics at Indiana University Bloomington. CAEPR can be found on the Internet at:

http://www.indiana.edu/ caepr. CAEPR can be reached via email at caepr@indiana.edu or via phone at 812-855-4050.

( 2008 by NAME. All rights reserved. Short sections of text, not to exceed two paragraphs, may be quoted without explicit permission provided that full credit, including $\odot$ notice, is given to the source. 


\title{
Policy Responses during the Depth of the 2007-09 Financial Crisis: Instrument Innovations, Executive Reconfigurations, and Legacies for U.S. Governance
}

\author{
George M. von Furstenberg \\ Dept. of Economics, Indiana University, Bloomington, IN USA vonfurst@indiana.edu \\ FinCrisis-GvonFurstenberg-IssuesC.doc, June 1, 2009
}

The period September 2008 - March 2009 encompassed that part of the long-festering financial crisis severe enough to leave troubling legacies for the conduct of economic policies. Executive discretion in economic governance hurriedly expanded and centralized to address the depth of the crisis. The U.S. Department of the Treasury (i.e., the Treasury), the Board of Governors of the Federal Reserve System (the Fed), and the Federal Deposit Insurance Corporation (FDIC) acting in tandem, freely exercised emergency authority to prop up the financial system. This paper shows these interventions to have short-run benefits and long-run costs for market efficiency and stability.

\section{Introduction}

Major crises, whether affecting health and environmental or economic safety or national-security interests at home and abroad tend to produce pervasive and long-lasting changes in the system of governance. The reason is that such crises -- whether precipitated by “Pearl Harbor” or an asset-bubble collapse and propagated by intermediation breakdowns and impending failures of systemically significant institutions -- inevitably lead to calls for urgent government action that needs to be coordinated at the highest levels. Regardless of whether the system that responds is parliamentary or presidential, it experiences a strengthening of the executive/administrative functions of 
government at the expense of the authority of the legislative and judicial branches. Inside the executive, in turn, any pre-existing dispersion of power over ministries and agencies is radically reduced in areas vital to crisis management. Respect for the independence of any of the federal agencies having oversight or regulatory responsibility in the areas affected by a crisis, even the self-respect of the staff and managers of such agencies, tends to be overridden by the perceived need to actively support the centrally-evolved rescue agenda.

This study shows that these two characteristics of response to crises, (i) strengthening of the executive, and (ii) centralization under a new or newly-empowered lead agency within the executive branch of government, are apparent in U.S. management of the current financial crisis. There is no space here to describe the multiplicity of crisismanagement and stimulus programs and their genesis and transformations comprehensively. It is also not possible to present and evaluate the changing official rationales of all the agencies involved in the management of the current crisis. . These rationales, some retrofitted, from Fed and Treasury perspectives, are detailed in Bernanke (2009, 2009a), Kashkari (2009), and Geithner (2009). Instead this paper focuses on programs that best elucidate the new form of government organization and the prospective consequences that derive from that new organization.

The next section, Section II, discusses the downside of the executive's assuming vastly more discretionary power. This power shift may reduce predictability and accountability and lower the consistency and steadiness of the policies and instruments used by the lead agencies dealing with the crisis. The result would be greater dependence on government good will and hence increased political risk for these agencies' 
institutional client populations. Section III turns to the loss of independence by agencies that are supposed to be independent within the executive branch of government. This loss of independence could affect, in particular, the Fed although the Fed has expanded its own sources of income along with its investments in, and guarantees of, risky assets. Crises inevitably strengthen the hand of those agencies and departments that can decide on the allocation of resources on a massive scale within very broad limits. Section IV summarizes the major findings on instrument innovations and reconfigurations in governance and the ways they may affect market efficiency and long-term performance.

The principal hands-on crisis managers were few, rarely more than three at any one time. The Fed is represented by the Chairman of the Board of Governors, Ben Bernanke, and it often acts through the Federal Reserve Bank of New York and its president (formerly Timothy Geithner). Geithner was sworn in as Secretary of the Treasury on January 26, 2009. His successor at the New York Fed, William Dudley, was appointed the next day. Geithner's predecessor at Treasury in the Bush Administration was Hank Paulson. Sheila Bair, Chairman of the FDIC, and Neel Kashkari, head of Treasury's new Office of Financial Stability, are holdovers who, like Bernanke, have served during both the Bush and Obama Administrations.

\section{Executive Assertiveness at Treasury: Haste Makes Waste?}

The management of major crises - whether of military and terrorist or economic and financial origin or attributable to natural disasters and epidemics - has always been viewed as a key contingent responsibility of government under its sovereign-protection and re-insurance functions. Hence, one need not agree fully with Higgs (1987) that 
governments exploit crises to threaten people's wealth and liberties, to maintain that severe emergencies and widespread crises strengthen the role of government and, in particular, the powers of the executive branch, in ways that may be difficult to reverse.

The rationales for the ascendancy of the executive branch during a real or supposed crisis center on the perceived necessity of unfettered and flexible discretionary management, rapidity of response, and coordination through centralization with little public debate or review. The claim is that the executive, when confronting perils to the nation, becomes the embodiment of national unity, the agent of mobilization, and the guardian of patriotic, lockstep resolve in times of crisis. ${ }^{1}$ Sweeping assertions of executive privilege and the exercise of broad discretion and concealment -- often with congressional and judicial acquiescence, and with little or no congressional or judicial oversight or well-informed prior authorization -- then follow from acceptance of this claim. Thus special powers tend to be acquired by the Office of the President and other executive offices and councils and by select officials and departments designated by the President to uydevise and execute the response to the crisis.

\section{I.A. Red Alert}

When the financial crisis deepened dramatically in the third week of September 2008, many of the above centripetal forces quickly asserted themselves. Indeed by September 21 at the end of that week, Treasury Secretary Paulson had crafted a three-page executive-empowerment document that would authorize the Secretary of the Treasury for two years to purchase troubled assets. Under the terms of this legislation, the total purchase price of such assets held by the Treasury at any given time can be no more than 
$\$ 700$ billion. This initiative was named the Troubled Asset Relief Program, TARP, when it was passed after the Congress had first rejected an earlier, unnamed, version. According to the original three pages of legislation sought by the Treasury, there was to be no Congressional interference with, or outside accountability for, funds spent under the authority of the Secretary of the Treasury: "Decisions by the Secretary pursuant to the authority of this Act are non-reviewable and committed at agency discretion, and may not be reviewed by any court of law or any administrative agency" (Sec. 8). The "financial institutions" from which troubled assets may be bought may include, "upon the Secretary's determination in consultation with the Chairman of the Board of Governors of the Federal Reserve, any institution he determines necessary to promote financial market stability” (Sec. 12(1)). This expansive definition, which was retained in the bill passed by Congress, allowed even General Motors and Chrysler eventually to qualify for assistance under TARP. Likewise "troubled assets" are defined to include mortgagerelated securities and "any other financial instrument" (Sec. 12(3)).

When Paulson's predictions of imminent financial meltdown failed to secure passage of this 3-page proposal on September 29, 2008, a much-more-elaborate and somewhat less presumptuous bill was hurriedly prepared and scheduled for fast-track consideration in the House and the Senate. Even so, before the Emergency Economic Stabilization Act (EESA) of 2008 was signed into law on October 3, 2008, Paulson had already moved away from the troubled-asset-purchase concept that gave the relief program, TARP, its name. He opted instead for direct injection of capital funds into financial institutions that he construed to have been authorized in a few lines of ESSA. As Roubini (2008) has pointed-out, these lines merely defined troubled assets of corporations, not liabilities like 
preferred equities which the Treasury may buy from them. Hence, until March 23, 2009, when the Treasury presented detailed plans to use $\$ 75$ to $\$ 100$ billion of the remaining TARP funds to purchase troubled assets in subsequent months under the Public-Private Investment Program (PPIP) for Legacy Assets, the central and express authority conferred by the TARP legislation remained unused. It turned-out therefore, that authority which the Treasury had claimed it urgently needed in September 2008 was not really used until at least May 2009, i.e., 8 or 9 months later. Rushing the Congress to pass a law that was put on the shelf except to extract from this law authority that the Congress had not intended ${ }^{2}$ indicates the extent of the erosion of legislative authority and the lack of steadiness in the executive branch.

The Treasury has stirred resentment in the Congress through a lack of transparency and consistency in other instances as well. While generally remaining passive, this resentment became active in one instance after Treasury had directed the Internal Revenue Service (IRS) to issue a tax ruling that disrespected the Congressional power of the purse. IRS notice 2008-83, the "Wells Fargo" notice, issued on September 30, 2008, allowed a handful of banks to use the built-in losses of banks they acquire without the limitations contained in Section 382 of the Internal Revenue Code of 1986 that severely cap their use. ${ }^{3}$ The Section-382 limitation for a taxable year after the ownership change for a "loss corporation" generally equals the fair market value of the stock of that corporation immediately before the ownership change multiplied by the long-term taxexempt interest rate published by the IRS. That rate was, for instance, $4.45 \%$ in October 2008 and 5.40\% in December 2008. Congress obtained partial redress in the American Recovery and Reinvestment Act of 2009 (the Obama Administration’s first “stimulus” 
bill) which found (H.R. 1, p. 320) that "Internal Revenue Service Notice 2008-83 is inconsistent with the congressional intent in enacting such section $382(\mathrm{~m}) .{ }^{4}$ The legal authority to prescribe Internal Revenue Service Notice 2008-83 is doubtful.”

That notice provided what turned out to be $\$ 29$ billion in tax benefits before it was declared as having "no force and effect with respect to any ownership change" prospectively, i.e., after the January 16, 2009 date mentioned in the stimulus bill. The sum of $\$ 29$ billion contained around \$20 billion in additional instant tax savings for Wells Fargo for its $\$ 14.8$ billion purchase of Wachovia, more than covering the cost of that purchase, and about $\$ 5.1$ billion in instant tax savings for PNC Financial Services Group for its takeover of National City Corporation. This stealth bailout for the benefit of Wachovia stockholders and the expense of taxpayers, although already in progress, was not revealed when Secretary Paulson issued a congratulatory statement on the sale of Wachovia Bank to what was at first planned to be Citigroup with the assistance of the FDIC $^{5}$ (Treasury Press Release HP-1164, September 29, 2008).

What this sequence of events shows is:

1. The Executive, in this case, the Treasury, can indeed move within days in a crisis, particularly if it feels unconstrained by the Congress or past government rules and practices. However, the quality of the strategic direction of these rapid actions has been low. It is not clear that a more-deliberative process that might have involved expert testimony at Congressional hearings would not have been helpful or that it would have caused undue delay.

2. The Treasury did not use the action program, TARP, it in the way it was initially announced and intended. Its preferred method to confront the crisis proved both 
flexible and erratic. Stress tests of troubled institutions that might allow the Treasury to devise an informed and adequate response did not begin until February 25, 2009. On that day a forward-looking supervisory assessment process or stress test, officially known as the Supervisory Capital Assessment Program (SCAP), was announced. It was made obligatory for domestic bank holding companies (BHCs), 19 in all, with yearend 2008 assets exceeding \$100 billion. The purpose of the SCAP, which was conducted by the federal bank regulatory agencies, was to assess whether the capital of these BHCs was adequate "to provide a buffer against higher losses than generally expected, and still [leave them] sufficiently capitalized over the next two years and able to lend to creditworthy borrowers should such losses materialize” (Board of Governors, 2009a, p. 1). When the results of these stress tests started to leak out in late April 2009, more than seven months had passed since the failure of Lehman Brothers had first created conditions of high alert. Hence, in the freneticism of the crisis, investments in informational prerequisites for prudent crisis management were long neglected.

3. In addressing the crisis, the Treasury made, or supported, deals benefiting individual institutions and stockholders arbitrarily and, in one or more cases, in possible violation of existing law. Arbitrary and irregular use of discretionary powers can undermine trust in the quality, competence, and evenhandedness of the government's crisis management and transfers to the private sector. It heightens uncertainty about the fate of individual institutions and adds political risk to their dealings with official parties. 
4. The Treasury joined the Fed as lender of last resort to certain targeted (e.g., Citigroup) or systemically significant, but failing (AIG), financial institutions. The Treasury set fairly stiff terms on the preferred nonvoting equity interests and warrants received for its capital injections as though these institutions were illiquid rather than insolvent. Within months, some of the dividend-paying cumulative preferred shares were converted into non-cumulative preferred or common equity paying no dividend. This step was taken in a new attempt to bolster the market's assessment of the quality of the capital position of these institutions and to lower their costs of capital. The resulting stock dilution put most of the 10-year warrants originally acquired by the government far out of the money, but high volatility coupled with the long exercise period still keep the warrants valuable. The TARP Reform and Accountability Act of 2009 that was passed by the House on January 21, 2009 but not taken up by the Senate ${ }^{6}$ insisted once again that "[u]nless otherwise specified, Treasury must obtain warrants equal to $15 \%$ [in exercise cost] of any financing provided.”

5. The focus of rescue missions kept blurring and shifting. The unsuccessful Act above also authorized the Treasury to allow repayment of TARP funds regardless of whether the recipient had replaced those funds with private capital as required under ESSA. This same provision then was included in the American Recovery and Reinvestment Act of 2009, passed by both Houses on February 13, 2009, with the injunction that the TARP recipient must consult with its federal banking agency prior to such replacement. Also, once the TARP funds are repaid, the Secretary of the Treasury must liquidate all warrants associated with the TARP 
recipient at the current market price. Since April 2009 there have been calls to relieve companies that opt to repay TARP funds early (at the liquidation value of the preferred equity acquired by the Treasury plus $5 \%$ annual dividends) of the requirement to repurchase the 10-year warrants at their - Black-Scholes or other estimated value. $^{7}$

The ostensible purpose of the Treasury’s $\$ 250$ billion Capital Purchase Program (CPP), which was announced on October 14, 2008 under TARP, was to inject capital into healthy institutions to stimulate lending. When institutions a few months later were allowed to opt out before they had raised additional capital, this objective had yielded to other priorities and concerns. The desire to get TARP funds back from healthy institutions for redeployment to others may have played a part since TARP authority limits the total balance that may be outstanding under the program at any one time. Furthermore, there may also have been a political desire to accommodate institutions that had come to regret taking TARP money (at 5\% for the first five years) for whatever reasons. ${ }^{8}$ A number of institutions had already repaid TARP funds by the end of April 2009. Around that time a proposal came up to make permission for doing so in the future conditional on demonstrating ability to issue debt without government assistance such as that provided by the FDIC’s TLGP guarantees described in Section III.E. Thus the weather under TARP kept changing.

6. Problems arise from softening the terms previously negotiated in an unforeseeable way whenever the condition of the corporations that have received equity or debt funds from the government has weakened dangerously. These problems are not 
only those of perverse incentives but also of making the outlook for the supported institution incalculable and, thus, fundamentally uncertain. The terms of implicit government insurance are highly speculative and exposed to changing political winds. Catastrophe bonds, by contrast, would be uncertainty-reducing. They provide for automatic softening of terms or debt cancellation when certain adverse events occur that are beyond the control of the insured party. Linking interest and dividend rates charged on U.S. investments in troubled financial institutions to a financial-sector stock-price index, like the Dow Jones U.S. Financials Index, could be a way of achieving greater conditional predictability of emergency concessions. ${ }^{9}$

7. Interests of taxpayers, emphasized in the TARP legislation, quickly were subordinated to maintaining private ownership of troubled institutions whose ability to return to the private capital market in the near future (except for Fannie Mae and Freddie Mac) was to be protected at all cost. As articulated on February 23, 2009 in a manner that was in part tautological and in whole illogical since financial institutions have not always been well managed in the private sector, "Because our economy functions better when financial institutions are well managed in the private sector, the strong presumption of the Capital Assistance Program is that banks should remain in private hands. ${ }^{10}$ For instance, the conversion terms for $\$ 25$ billion CPP portion ${ }^{11}$ of the $\$ 45$ billion of preferred shares held by the Treasury in Citigroup valued common equity at \$3.25 a share, which was more than twice the opening price (\$1.56) of Citigroup shares on the morning of February 27, 2009, ${ }^{12}$ right after the announcement, and 32\% above the 
closing price (\$2.46) on the previous day. Measured against Citigroup’s \$25.99 book value per share, this conversion at $\$ 3.25$ per share was highly dilutive, but measured against market price it was strongly anti-dilutive to the benefit of Citigroup. Only Fannie Mae and Freddie Mac, whose balance sheets are being poisoned with high loan-to-value ratio mortgages bearing below-market interest rates, are not expected to emerge anytime soon from the conservatorship in which they were placed on September 7, 2008.

\section{Intra-Governmental Centralization: Lasting Loss of Institutional Independence?}

In the grip of a major crisis, there does not seem time for careful debate and deliberation either in the legislative branch or between executive departments and agencies with different mandates, priorities, clientele, and perspectives. Speed, centrallydirected resolve, and unity in execution appear to be at a premium at such a time, and irresolution, public disagreement, and bureaucratic infighting the enemy. To sustain such willing delegation to the top, Prime Ministers eventually have to become Churchillian and Presidents Rooseveltian lest they perish politically for being unable to instill a vision that gains and holds the electorate's confidence.

The intense stage of the financial crisis from September 2008 to March 2009 started in the United States under a lame-duck President and continued under a newly-elected successor. However, centralization of crisis-management within the executive branch, involving some of the same lead actors (in particular, Bernanke, Geithner, Bair, and Kashkari), has already been evident under each of these Presidents. This section provides 
and discusses indicators of this tendency and the way it could affect the Fed's operating environment and independence.

One of the remarkable features of the 2008-09 crisis is that rescue operations for financial institutions have often taken the form of joint agreements of such institutions with (i) the Treasury, (ii) the Fed, (iii) the Federal Deposit Insurance Corporation (FDIC), and (iv) possibly two ${ }^{13}$ more federal banking agencies other than the Fed and the FDIC, simultaneously. ${ }^{14}$ The November 23, 2008, Joint Statement on Citigroup, the January 16, 2009, Joint Statement on Bank of America, and the Joint statement of Treasury and Fed on the AIG Restructuring plan of March 2, 2009 are examples. They are detailed in Section II.A(a) and II.A(b) later on. Other types of joint statements serve mainly to present a united front in introducing "comprehensive” rescue programs in which the Treasury, Fed, and FDIC participate synergistically or to clarify role assignments. Two examples will suffice:

- October 14, 2008, Joint Statement by Treasury, Federal Reserve, and FDIC. This statement announced first the establishment of the Treasury’s “voluntary” Capital Purchase Program (CPP) by making a broad array of financial institutions eligible to sell preferred shares to the U.S. government “on attractive terms that protect the taxpayer.” Secondly, Treasury agreed to activate the "systemic risk exception" to the FDIC Act after consulting with the FDIC, the Fed, and with the President. This exception was cited to allow the FDIC temporarily to guarantee the senior debt of all FDIC-insured institutions and their holding companies as well as deposits in non-interest bearing deposit transaction accounts (used by business) under what came to be known as the Temporary Liquidity Guarantee Program 
(TLGP). ${ }^{15}$ Third, the Fed set forth further details of the Commercial Paper

Funding Facility (CPFF), which increases the funding opportunities of businesses that had been shut out of markets for particular securities The Facility, that was originally set to close for new business on April 30, 2009, provides a broad backstop for the CP market by funding purchases of such paper from high-quality issuers.

- February 10, 2009, Joint Statement by Treasury, Fed, FDIC, OCC, and OTS on Financial Stability Plan. This statement sought to provide a framework for a number of elements on which details were announced on March 23, 2009. These include: (i) A new Capital Assistance Program (CAP) program for banks with assets exceeding $\$ 100$ billion which have undergone a forward-looking economic assessments and stress test designed to identify their contingent needs for additional capital and (ii) a Public-Private Investment Fund (PPIF) for pools of legacy loans and other assets with a potential to expand to $\$ 1$ trillion to realize some of the original intentions of TARP without relying solely on Treasury financing for the purchase of troubled assets. The individual Funds would be $85 \%$ financed by loans with the help of loan guarantees from the FDIC, and Treasury would put up half the equity financing of the remainder in partnership with the private investment group in the fund. Commencement of the stress test itself was announced by the federal banking regulatory agencies on February 25, 2009. (iii) A new initiative to expand dramatically, up to $\$ 1$ trillion, the existing Term AssetBacked Securities Lending Facility (TALF, see Section II.A(c)), and to make the facility available for legacy securities and not only for ABS constituted from new 
loans to consumers and small businesses and (iv) an extension of the FDIC's TLGP by four months to October 31, 2009.

"Fusion" government and resolving interagency conflicts quickly and at the highest levels internally and out-of-sight are common mechanisms for coping with daily demands in major crises. The downside is that agency representatives roped into common endeavors are degraded to obliging team players loath to challenge whatever groupthink may hold sway. Rushing jointly from emergency decision to decision and creating one barely examined fait accompli after another may not add up to a coherent and sustainable strategy or facilitate discovery of a more-nearly-optimal path. Haste makes waste; regret sets in quickly over how poorly things were done in the first place, as in spending the first half, \$350 billion, of the TARP funds. Things then tend to get redone additional times before decision-making is based solidly on more-comprehensive knowledge and analysis of the problem. The fact that it took until February 25, 2009, almost half a year from the onset of the severest stage of the current financial crisis, for the major banking and financial institutions to be obliged to size-up their actual or potential survival risks is a case in point. Only then did they start to undergo stress tests from their primary federal banking regulator under the overall supervision of the Fed to determine what type and amount of support from either the private market or, failing that, the government they would require under specified conditions. ${ }^{16}$ To bolster capital through government "investment" as sparingly as possible, the Treasury might offer to acquire a special class of preferred equity, representing stand-by common equity, from financial institutions. This class of preferred shares could be converted into common equity only upon demand 
by either party when and if needed so as to keep the government's ownership stake as small as possible in the interim.

Rushing out treatments while lacking a firm diagnosis of the nature and extent of the main problems inevitably leads to wasteful improvisation, frequent reversals, and almost constant program modifications. Without good priors there is little opportunity for efficient learning by doing, and much room for flailing-about in a crisis. This analysis applies to TARP, a program that Treasury redirected from troubled-asset purchases to capital injections into both teetering and healthy institutions, but had submitted for approval in its earlier form to the U.S. Congress. It also applies to the instruments chosen and the terms set and then quickly discarded. Thus, it is almost farcical to observe that the Fed charged AIG, an insolvent and not just illiquid institution, a penalty rate of LIBOR plus 850 basis points (bp) for funds drawn from a revolving credit facility it had established for the insurance company in September 2008. At that time the 3-month LIBOR rate was over 3\% but LIBOR rose to more than $4 \%$ in October so that AIG's penalty rate was $11.5 \%$ to $12.5 \%$. In November the Fed lowered the interest rate on funds drawn in effect to $6.50 \%$ and further to about $4.25 \%$ by early March 2009 . The rate on undrawn funds under this facility was cut from a punishing 850bp to a mere 75bp in one fell swoop.

The lesson of these repeated rewritings of contracts should be obvious: Do not make contracts with private parties in difficulty that feel secure in the knowledge of being too big to fail. Such parties cannot be expected to honor contracts with the government because they are rewarded with additional aid, rather than effectively penalized, if they are unable to fulfill the terms of their contracts with the government. In this respect the 
hardening of congressional attitudes against any further appropriations for TARP-like bailouts since January 2009 is a welcome development. It imposes firmer budget constraints on the Treasury and hence on its dealings with private parties, so that newer contracts may be less readily watered down.

Until at least March 2009, however, the Treasury has been as eager as the Fed to act tough and then bury the big stick. It charged AIG a cumulative dividend of $10 \%$ for TARP funds in October 2008, but that dividend was made non-cumulative and hence suspended in March 2009 for as long as AIG Directors are in no position to declare dividends on non-cumulative preferred equity. In its third crack at saving Citigroup on February 27, 2009, the Treasury went even further. It required conversion of the liquidation value of cumulative preferred with a $5 \%$ initial dividend not just to noncumulative preferred but to common stock, and at a conversion price far above the depressed market price as detailed earlier. Dividend payments above 1 cent a quarter are prohibited on common stock under the TARP until the government has been bought out. The \$25 billion of cumulative preferred equity that was converted to common stock had been issued to Citigroup under the Treasury's October 14, 2008 CPP on October 26, 2008. Table 1 helps keep track of the original commitments of TARP funds under Treasury Secretary Paulson in the Bush Administration.

\section{III.A Mutual Dependence and Joint Loss Absorption by Treasury, Fed, and FDIC}

The three government departments or agencies have cooperated in rescue programs for banks and for some non-banks, they have jointly issued asset guarantees, and the Treasury has provided a backstop for losses from the purchase of risky assets by the Fed. 
Among the government participants, a seniority structure has been negotiated for any loss-absorption resulting from these guarantee activities. The management of any of the projects or programs involving contingent joint liability or backstopping clearly directly affects all those exposed. Examples are provided by (a) The Targeted Investment Program (TIP), initiated on November 23, 2008 for the benefit of Citigroup and then used on January 16, 2009 also for Bank of America, (b) the serial rescues of AIG, and (c) the Term Asset-Backed Securities Loan Facility, TALF.

(a) The Targeted Investment Program (TIP). TIP was initiated on November 23, 2008 first for the benefit of Citigroup, which had already benefited from a CPP investment by the Treasury less than a month earlier. Since that time, TIP was used on January 16, 2009 for a similar additional capital injection into Bank of America, with the government also providing protection against deep losses on $\$ 118$ billion in selected capital markets exposure, primarily from the former Merrill Lynch portfolio. Federal guarantee programs typically limit the loss to the owner of the portfolio that is put up for guarantee to a fixed front-end amount plus a small percentage of all greater losses. However, if the companies to be aided by the guarantees are unable to honor the loss participation to which they have agreed without becoming undercapitalized, they can presumably expect further government help as long as they are regarded as "too big to (let) fail.” Hence, in the presence of soft budget constraints, the finality of the loss participations negotiated by the Treasury may be in doubt. It is also not clear what valuation method was used to establish (i) the values of the troubled assets that have been guaranteed and hence (ii) the severity of the risks faced by the guarantors. 
The Citigroup guarantees issued under TIP protect it against "unusually large losses on an asset pool of approximately \$301 [originally \$306] billion of loans and securities backed by residential and commercial real estate and other such assets, which will remain on Citigroup’s balance sheet” (U.S. Department of the Treasury, 2009). The guarantee is in place for 10 years for residential, and for 5 years for non-residential assets. As a fee for this arrangement, Citigroup issued $\$ 4$ billion of preferred stock at an $8 \%$ dividend rate to the Treasury and \$3 billion to FDIC. Citigroup is to absorb all losses up to \$29 billion, subsequently raised to $\$ 39.5$ billion, ${ }^{17}$ in this portfolio, the declared risk-weighting of which is $20 \%$. Citigroup is also responsible for $10 \%$ of any larger losses while Treasury, via TARP, is to bear any second loss up to \$5 billion, and the FDIC any third loss up to $\$ 10$ billion. The Federal Reserve funds the remaining pool of assets with a non-recourse loan facility, subject to Citigroup’s 10\% loss sharing. It charges a fee of 20bp per annum on undrawn amounts and a floating interest rate equal to the Overnight Indexed Swap $(\mathrm{OIS})^{18}$ rate plus 300bp per annum on drawn amounts. In the event that the asset pool should turn out to be worth only \$201 billion rather than \$301 billion, Treasury thus would be on the hook for $\$ 5$ billion, the FDIC for $\$ 10$ billion, and the Fed for 0.9(10039.5) $-5-10=\$ 39.45$ billion.

On January 16, 2009, Bank of America (BAC) became the second beneficiary of the evolving Asset Guarantee Program under TIP. BAC received protection against \$118 billion in capital-market exposure for a fee of $\$ 4$ billion of preferred stock with an $8 \%$ dividend and warrants with an aggregate exercise value of $10 \%$ of the total amount of preferred issued. BAC would cover the first $\$ 10$ billion of losses, and the government would cover $90 \%$ of any subsequent losses. The Treasury would be first in line to absorb 
up to $\$ 7.5$ billion of the losses not charged to BAC, followed by FDIC with up to $\$ 2.5$ billion, and the Fed with up to 0.9(118-10) -7.5 - $2.5=\$ 87.2$ billion. Again, if the BAC portfolio being guaranteed should turn out to retain only about two-thirds of its value ( $\$ 78$ billion), the Fed's liability would be $\$ 17$ billion of the $\$ 40$ billion loss of value, $\$ 13$ billion of which would be borne by BAC.

(b) The series of support actions for AIG and the Maiden Lane LLCs. Although the Fed is not AIG's regulator, the global insurance company on September 11-12, 2008 revealed its urgent need for liquidity help to the Federal Reserve Bank of New York. Within days after its plea, government support began with the Federal Reserve's establishing an \$85-billion Revolving Credit Facility (RFC) for AIG on September 16, 2008, a day after the investment bank Lehman Brothers was allowed to fail. A few days later the Treasury acquired special Series C preferred stock representing a 77.9-percent equity interest in AIG for $\$ 0.5$ billion. Less than two months later, the Treasury made a \$40-billion investment in cumulative preferred equity in AIG plus warrants under what came to be known as the Systemically Significant Failing Institutions Program (SSFIP) under TARP. AIG received an additional \$38-billion credit line from the Fed on October 8, 2008 and \$21 billion more on October 30 as part of the central bank’s support for AIG's securities-lending and commercial-paper financing operations, respectively. This set of supporting actions was followed on November 10, 2008 with a \$25-billion reduction in the RCF in view the Treasury's $\$ 40$ billion investment in AIG through TARP at about the same time. In addition, cheaper funds than available from the RCF had become available to AIG under the Commercial Paper Funding Facility (CPFF). GAO (2009) provides a convenient timeline of AIG financial difficulties leading up to 
Federal assistance and details the amount of AIG assistance used (total: \$126 billion) and authorized (total: \$183 billion) through March 2, 2009.

The (New York) Fed was further authorized on November 10 to establish and lend to two Limited Liability Companies (LLCs) that bore the same name, Maiden Lane, ${ }^{19}$ as the first such creature that had been used to facilitate the acquisition of Bear Stearns by JPMorgan Chase on June 26, 2008. Maiden Lane II LLC was formed on December 12, 2008 with a $\$ 1$-billion subordinated loan from AIG and up to $\$ 22.5$ billion from the New York Fed to help shut down AIG's securities-lending business. This support was provided by purchasing mortgage-backed securities from the U.S.-securities-lendingreinvestment portfolio of AIG subsidiaries. Maiden Lane III LLC was established on November 25, 2008. AIG had acquired collateralized debt obligations (CDOs) on which its Financial Products Group had written what turned out to be ruinous credit default swaps (CDSs) that needed to be unwound. Maiden Lane III was to be this "CDS shutdown” facility. It was funded with a \$5-billion common equity investment in the LLC by AIG and with up to $\$ 30$ billion in loans from the New York Fed at an interest rate of 1-month LIBOR plus 100 basis points.

It may be useful to note here that the level of the interest rates charged by the Fed on its loans to the LLCs, while generally very low, is of little operational significance if the Fed is the sole beneficiary of any residual incomes left upon closeout of the LLCs. The Fed is the sole residual beneficiary in the case of Maiden Lane I, but not II (5/6) and III (2/3). Splitting any residual cash flow with a private investment partner or partners prefigures the arrangement chosen for the PPIF announced on March 23, 2009 except 
that, in Maiden Lane LLC, the private partner is the entity putting up the asset which it itself, and not someone else, had originated or acquired by merger.

As conveniently recorded on a Federal Reserve Bank of St. Louis web site ${ }^{20}$ that presents time series for Wednesdays obtained from the Fed's H.4.1 releases, on February 25, 2009, Maiden Lane I LLC was \$4,338 million under water, using fair-value estimates of the net portfolio holdings as of December 31, 2008. Of this amount of accrued loss $\$ 1,197$ million, representing a principal amount of $\$ 1$ billion and accrued interest, was for JPMorgan Chase, and the remaining \$3,141 million for the Fed to recognize. Maiden Lane II LLC was \$1,256 million under, with only \$248 million to be recognized by the Fed and all the rest by AIG. Because AIG's front-off participation in any losses is much larger in Maiden Lane III LLC, the entire \$1,792 million loss was its own responsibility. Hence in these three facilities combined, the Fed's investment, by Wednesday, February 25 , 2009, had experienced a loss of about $\$ 3.4$ billion. This figure is almost 5\% of the outstanding principal amount of loans extended by the Federal Reserve Bank of New York to these LLCs (plus accrued interest), which comes to $\$ 72.4$ billion. Because these portfolio losses of the Fed have grown over time, tending to be highest on the oldest Special Purpose Vehicles (SPVs), indeed $10.8 \%$ for Maiden Lane I LLC, it may be prudent to assume an eventual $10 \%$, rather than $5 \%$, loss rate on Fed loans to such SPVs.

On March 2, 2009, several of these support actions for AIG were changed and supplemented further. A statement issued jointly by the Treasury and the Fed provided for conversion of $\$ 40$ billion of cumulative preferred equity to non-cumulative preferred equity held by Treasury and granted a $\$ 30$-billion line for placing additional issues of such equity with the Treasury. The steep cumulative dividend rate of $10 \%$, with severe 
penalties for prolonged non-payment that had been set in the original capital injection in November 2008, thus was not long maintained. The $\$ 60$ billion remaining from the $\$ 85-$ billion Revolving Credit Facility originally granted by the Fed in September 2008 was reduced by no more than $\$ 35$ billion to take account of other financing received by AIG for shedding assets. That financing consisted of (a) preferred-equity interests of around \$26 billion acquired by the New York Fed in two SPVs created to hold the outstanding common stock of two foreign life insurance subsidiaries of AIG and (b) an \$8.5-billion loan by the Fed to another SPV established by domestic life insurance subsidiaries of AIG.

Again using the prudent 10\%-loss provision percentage previously derived, a loss of \$3.5 billion may be expected on these two SPVs combined. Together with the $\$ 7.24$ billion from the three Maiden Lane LLCs, AIG-related losses to the Fed may be $\$ 10$ $\$ 11$ billion. As already noted, the floating interest rate on the no less than $\$ 25$ billion that will then remain of the Revolving Credit Facility (RFC) was reset from 3-month LIBOR plus 300 basis points but no less than 6.5\%, to simply 3-month LIBOR plus 300 basis points, a figure of only 4.27\% on March 3, 2009.

Because the RFC continues to be secured by a lien on a substantial portion of AIG's remaining assets, no loss provision is made. Indeed fees of 75bp may be earned on the undrawn amount of the no less than $\$ 25$ billion left in this facility. There may also be a profit, at least without adjusting for default risk which the Fed may deflect, on the amount drawn which bears interest at 300bp above 3-month LIBOR. This combined rate in winter 2009 was far above the Fed's own marginal cost of funds of just $1 \frac{14 \%}{4}$ paid on the excess reserves it generated for its depository institutions. However, to the extent 
assets sold by AIG to the Fed's LLCs are underpriced, the value of the Treasury's residual ownership stake in AIG and that of the private minority shareholders may be hollowed out. Conversely, if these assets are overpriced, a Fed subsidy benefiting these other stakeholders is involved.

All combined, the Fed's representations to the contrary notwithstanding, it may be prudent for the Fed to anticipate a loss of at least $\$ 10$ billion on its AIG-related loans, investments, and SPVs.

(c) The Term Asset-Backed Securities Loan Facility (TALF). TALF, the original part of which commenced operations in March 2009 after having been on the drawing boards since its creation on November 25, 2008, has already been set-up with a $10 \%$ loss provision after haircuts. The Treasury eventually committed up to $\$ 100$ billion of TARP funds to absorb losses that may be incurred on the up to $\$ 1$ trillion of eligible assets. On March 23, 2009, TALF was extended from helping to finance the acquisition of ABS formed with newly issued securities to ABS collateralized by legacy securities that had been originated prior to 2009. Hence "eligible assets" now may include "legacy securities" acquired by the Fed under TALF. These legacy securities are to be tied to residential and commercial real estate ${ }^{21}$ and consumer credit with a rating of AAA at origination.

This definition of eligible assets, which includes non-agency Commercial and Residential Mortgage-Backed Securities (CMBS and RMBS), is the same as that for the "Legacy Securities Public-Private Investment Funds (PPIFs)" to be assembled under the corresponding Program (PPIP) announced by the Treasury also on March 23, 2009. ${ }^{22}$ Non-recourse loans from the Treasury may go up to either $50 \%$ or $100 \%$ of the equity 
capital raised for these funds in equal parts from the Treasury and private sources, with the interest rates on these loans to be determined by the Treasury. Adding loans from other sources may then allow $\$ 75$ billion to $\$ 100$ billion in TARP capital to generate \$500 billion in purchasing power to buy legacy assets under the PPIP. Any residual income generated by a fund from the eventual disposition of these assets will be divided between the Treasury and the applicable private vehicle based on equity contributions. However, Treasury will have taken warrants from private investors (i.e., listed companies) as required by EESA to protect the interests of taxpayers to some degree.

Under the original part of the TALF program announced in November 2008, the Fed buys AAA-rated, but nonetheless risky, instruments, such as securities backed by different types of consumer and business credit, including credit-card, auto, student, and small- business loans. Interest rates on TALF loans secured by Small Business Administration Pool Certificates are as low as 1 percent when the target federal funds rate is $0.25 \%$. Loans secured by other eligible floating- rate ABS have rates at most 100 basis points above the 3-year LIBOR swap rate. TALF loans are financed mostly through additions to the Fed's liability for excess reserves owed to depository institutions so that a large rate spread is built in. Unless the net loss rate in this program exceeds $10 \%$, the Fed is not at risk under TALF, and the Treasury will undoubtedly be pressing for a loss rate lower than $10 \%$ to reduce the cost of its guarantee since, after the "haircut," it is next in line on the loss absorption schedule.

The Fed's loans to the CPFF LLC also appear safe and adequately buffered with accumulated earnings of \$1 billion for the period October 14 through December 31, 2008 standing against loans payable of $\$ 332$ billion and total assets of $\$ 335$ billion at the end 
of this period. Commercial paper holdings included in the latter figure have been reported at book value, i.e., amortized cost plus related fees, because there has been no evidence of other-than-temporary impairment.

Nevertheless the loss provisions agreed to for TALF again show the extent of the interdependence among government agencies in confronting the financial crisis with each other's means. Eligible borrowers use a primary dealer to access the TALF and to deliver eligible collateral subject to a "haircut," of $10 \%$ or less, to the New York Fed's custodian bank. All except the haircut is public (Fed) money on very favorable terms; all residual gains are private. To hold the Fed harmless in case of loss on TALF investments, any forfeited collateral goes at the originally agreed loan value, which is net of the haircut, to an SPV funded by Treasury that is to dispose of the impaired assets and absorb any losses. Given these cross-exposures, the government entities involved need to coordinate, interact, and support each other constantly as a team and must come to a joint resolution. Hence independence for any one of them, going it alone, or minding one’s own business and mandate, are no longer an option for the organized "public partnership" which has emerged. ${ }^{23}$

\section{III.B Fiscal Threats to Fed Independence?}

Section III.A presented estimates, based on crude conjectures, suggesting that the Fed may face losses of about $\$ 56.5$ billion under TIP assuming the values of the portfolios guaranteed for Citigroup and Bank of America turn out to be one-third below the levels of their respective guaranteed amounts. It may face another $\$ 10$ billion of losses in conjunction with its Bear Stearns and AIG-related senior SPV funding, assuming that the 
value of these LLCs ultimately falls to a level that would involve a 10\% loss on the Fed loans that provide most of the funding for them. This combined future loss of $\$ 66.5$ billion exceeds the $\$ 46$ billion of "total capital" reported in the consolidated statement of condition of all Federal Reserve banks in the Fed's H.4.1 release of April 22, 2009.

Since realization of this estimated loss would be spread out over a decade and since other sources of the Fed's income may grow strongly in the interim, the gap between these two amounts need not imply that the bailer, in this case the Fed, may soon itself need an unscheduled bailout from the Treasury. Yet some have worried that should the Fed ever find itself in such a sorry position, "without a firm guarantee up front that the federal government will fully recapitalize the Fed for losses suffered as a result of the Fed's exposure to private credit risk" realizing and financing any such losses could come at the price of pursuing "the monetary policy desired by the U.S. Treasury" (Smith, 2009). This worry ignores that the Fed cannot afford to act independently of the Treasury (and the FDIC), and vice versa, as long as the intra-governmental crisis-management partnership must be maintained. Hence, the Fed's becoming fiscally dependent on the Treasury could become an obstacle to its regaining independence only well after the crisis has passed.

The most obvious permanent fiscal income linkage between the Treasury and the Fed comes from the Federal Reserve banks' contributing a substantial share of the Treasury’s receipts from taxes on corporate income. In 2007 (2008) this share was \$34.6 (32.7) billion out of $\$ 365.4$ (291.1) billion, or almost 10\% (over $11 \%$ ). ${ }^{24}$ Technically, this annual flow seigniorage of more than $\$ 30$ billion is described as payment to the U.S. Treasury that represents interest on Federal Reserve notes which must be collateralized 
by the Fed. Qualifying assets include the Fed's gold-certificate account and specialdrawing-rights-certificate account balances, and U.S. Treasury and agency debt and mortgage-backed securities (MBS) pledged. At the end of 2007 (2008), the collateralized Federal Reserve notes were equal in value to all such notes outstanding net of notes held by the Federal Reserve banks, or $\$ 791.7$ (853.2) billion. ${ }^{25}$ The payment of $\$ 34.6$ (32.7) billion to the Treasury represents $4.37 \%$ (3.83\%) of the respective total. For comparison, the average yield on 3-month Treasury bills was 4.41\% (1.48\%) in 2007 (2008).

The Fed announced on November 25, 2008 that, starting in 2009, it planned to purchase up to $\$ 100$ billion of the mortgages and MBS retained by Fannie Mae and Freddie Mac (GSE direct obligations) and up to $\$ 500$ billion in MBS guaranteed by these institutions or Ginnie Mae. ${ }^{26}$ The Treasury had received temporary authority to purchase any obligations and other securities in any amount issued by the GSEs involved in the mortgage market already in the Housing and Economic Recovery Act of 2008 signed into law on July 30, 2008. It used this authority first on September 7, 2008 when it acquired a 79.9\% ownership stake in Fannie Mae and Freddie Mac and extended funding commitments of $\$ 100$ billion to each. These institutions now are operating under conservatorship which is a form of bankruptcy in which a government agency, in this case the Treasury, acts as bankruptcy judge who may be authorized to convey government grants and subsidies to keep the federal housing agencies going indefinitely.

When the Fed jumped in less than 3 months after the Treasury, it could reduce its holdings of Treasury securities for use as collateral for Federal Reserve Notes by the amount of any agency securities or MBS acquired. Since the interest-rate on these obligations exceeds that on U.S. Treasury securities, the Fed's “comprehensive income 
before payment to the U.S. Treasury” would rise. That income, $\$ 38,716(35,504)$ million in 2007 (2008), that is included in corporate income in the National Income and Product Accounts (NIPA) of the United States, was used by the Federal Reserve banks to pay \$992 $(1,189)$ million in dividends, add $\$ 3,126(2,626)$ million to their surplus, and remit the remainder to the Treasury as "interest on Federal Reserve notes". ${ }^{27}$

If paying less than $100 \%$ of the Fed's income to the Treasury is meant to continue so that the capital of the Federal Reserve banks keeps growing, whatever affects the income of the Federal Reserve system also affects that of the Treasury and, hence, that of the U.S. taxpayer. Should the Fed's income shrink well below the earnings attributable to the collateral for the note issue, or even become negative in normal times well past the 20082009 crisis, the Fed could find its independence comprised by its inability to continue to pay to the Treasury anything resembling appropriate interest on the notes issue.

It is as yet very difficult to estimate net receipts from current and future fees and spreads in all of the Fed's growing list of capital-market relief programs. Making permanent the payment of interest on the reserves of depository institutions could reduce the Fed's income but only if one ignores the huge expansion ${ }^{28}$ of such reserves that called for this policy change. Obviously, as long as the upper range of the federal funds rate target is $1 / 4 \%$ and that is all the Fed pays on both required and excess reserves, balancesheet expansion through increasing reserves greatly raises Fed income absolutely even if the average rate of return on its total assets falls. ${ }^{29}$

The problem is that, once the Fed's balance sheet must shrink, capital-market and maturity-mismatch risks arise to the extent that assets, unlike those contained in the Fed's "liquidity" programs and facilities, have long maturities and fixed interest rates. The up 
to $\$ 1.25$ trillion total of agency MBS and the up to $\$ 300$ billion of "longer-term" Treasury securities (to be) acquired by the Fed according to the (FOMC) announcement of March 18, 2009 clearly fit this description since ARMs generally will not be included. ${ }^{30}$ This ill-considered "quantitative easing" operation involves an attempt to drive interest rates on fixed-rate, long-term instruments free of default risk (to the investor, if agency-guaranteed) below sustainable levels. ${ }^{31}$ If fully implemented, this investment in agency MBS and longer-term Treasuries could subject the Fed to very considerable risks, for instance, if the dollar should weaken so much in international markets that inflation expectations and nominal interest rates were to be forced up. The Federal Open Market Committee (FOMC) has repeated the mantra that it "anticipates that economic conditions are likely to warrant exceptionally low levels of the federal funds rate for an extended period". ${ }^{32}$ But this FOMC assessment represents a speculation on continued low inflation and fair sailing ahead for the U.S. dollar. Should the federalfunds rate target have to be raised appreciably, mark-to-market losses on the Fed's holding of agency mortgage backed securities and longer-term Treasuries would rise. Contracting the Fed's balance sheet at the required speed thus could lead to realized losses. Hence the Fed may seek to maintain positions in these securities with unrealized capital losses as long as they yield positive cash flow and facilitate extensive crosssubsidization with other Fed programs. This in turn could provide a bureaucratic incentive for the Fed to keep interest rates on excess reserves low for longer than desirable, hoping that their holders will not become restless and try to shed excess reserves, causing inflation. 


\section{III.C Threats to the Fed's Reputation?}

An even-more-serious problem than the loss of fiscal independence for the Fed as a result of its latest programs is that these programs may tarnish its reputation. In a remarkable "Joint Statement by the Department of the Treasury and the Federal Reserve" issued on March 23, $2009^{33}$ the Treasury and the Fed agreed that the Fed would avoid credit risk and credit allocation. Its actions were not to allocate credit to narrowly-defined sectors or classes of borrowers because "[g]overnment decisions to influence the allocation of credit are the province of the fiscal authorities.”

Unfortunately this vision of the Fed's role in preserving financial and monetary stability does not match what it has done in the depth of the financial crisis and continues to do even after March 2009, for instance in the mortgage market. In a political system, the independence of an agency ultimately is predicated on the respect its mission and “independent” modus operandi command. Yet engaging in official interventions to depress long rates on securities free from default risk that are traded in highly liquid international markets does not deserve such respect. None of the justifications offered for all the Fed's previous liquidity and credit programs in the current crisis, such as the need to restore the normal functioning of financial intermediaries and credit markets, could possibly apply to such operations.

These operations, which are designed to reduce rates on mortgages guaranteed by the federal housing agencies and on long-term government securities even after the target federal funds rate has reached bottom, are sadly reminiscent of the "nudge and twist" operation of 1961-62. That operation tried to rely on portfolio-composition effects by maturity to defeat the economic logic of the term structure of interest rates represented by 
the expectations hypothesis cum term premiums. It did so by attempting to lower rates on long-term government securities (to help pull down other long rates and to stimulate business investment in the incipient recovery) without reducing short rates (thereby attracting more private foreign short-term investors without scaring away foreign official investors who kept raising their holdings of paper claims on the United States while also threatening to demand gold). The Federal Reserve thus began to purchase Treasury notes and bonds with maturities greater than one year and sell short-term Treasury securities. Hafer (2005, p. 291) provides the full account and notes that there was little evidence that the operation was successful in flattening the term structure. In the same vein, Bloomberg reported on March 27, 2009 that "Treasuries were little changed as the Federal Reserve bought $\$ 7.5$ billion in U.S. debt for the second time in three days as part of a program to hold down borrowing costs and revive the economy.”

Persisting in the attempt to distort, or twist, the treasury and agency yield curves, the Fed has announced further small purchases of treasuries with maturities from 3 to 30 years as it seeks to buy up to $\$ 300$ billion of U.S. government debt over the next six months. Purchases of MBS have started more aggressively. Around the time of the announcement in March, the Fed acquired \$236 billion of agency MBS and then bought another $\$ 132$ billion in the following weeks bringing the total to $\$ 368$ billion by April 22, 2009. In its H.4.1 release, under “Maturity Distribution,” the MBS are listed as “over 10 years."

Instead of being too high in March 2009, the problem for the future appears to be that the yield on long-term government-related securities has been too depressed for longterm good. Home mortgage yields declined to well below 5\% because originators could 
depend on the federal housing agencies buying them at par plus origination fees. These agencies then would hold the mortgages in their own portfolio, or, more often, as backing for agency-guaranteed MBS, which, in turn, may be bought by the Fed. The result is mortgage yields well below the level that would be required in unassisted markets. Imagine a return to equilibrium within a few years with the real interest rate at $2 \%$, desired and actual inflation at 2\% and output back at its "potential” level. Then the normal Taylor-rule target level of the federal funds rate would be around $4 \%$. Add to that a 10-year term premium of just 1 percentage point and the yield on U.S. Treasuries with a constant maturity of 10 years would be around 5\% (CBO, 2007). In fact it has been under 3\% from December 2008 to at least April 2009. Thus, within a few years, portfolios that had acquired 10-year securities at these low yields will find their acquisitions truly noxious not because they carry any default risk but because their interest rates are too low to cover the cost of funds and their yields too low to prevent steep capital losses. For instance, the situation of a buyer of 30-year government bonds, yielding 3.6\% in March 2009, could become quite dire in a few years. The normal yield required on the seasoned, originally 30 -year, bonds would be around $5.5 \%$ and capital losses would be over $25 \%$ of the March 2009 investment 5 years later. The yield deficiency, generated by government intervention in the mortgage market and subsidization of home mortgage credit, thus prevents the restoration of the "originate and hold" model just when the "originate and distribute" model had become notorious for mismanaging and underpricing risks whose incidence was obscured through layers of securitization.

Also in March 2009, the contract interest rate on conventional mortgages stood at $4.8 \%$. That rate was already too low to keep such lending commercially viable without 
government assistance. It would support agency MBS yielding little more than $4 \%$ after all the intermediation, servicing, and guarantee fees have been subtracted. But $4 \%$ is the expected level of the federal funds rate once the economy has recovered if the expected inflation rate holds steady at $2 \%$. Conventional uninsured mortgages originated at loanvalue ratios of no more than $80 \%$ then would have to yield at least $6 \%$ to be interesting for private originators to hold or to use as collateral for non-agency MBS. Hence, there will be no happy ending to the Fed's reliance on unsound federal housing agencies to deliver below-market mortgage finance while their liabilities and guarantees are backed by the full faith and credit of the U.S. government and taxpayers. The Treasury does not need the Fed to alter the maturity structure of the public debt, and its intervention is uncalled for in the mortgage market. Contrary to the Fed's protestations, the latter intervention would also be far from sector-neutral, should it succeed in further lowering already depressed mortgage interest rates as is its objective. To the extent the Fed does not succeed in this respect, it still harms its balance sheet and reputation.

The current crisis has also given rise to entirely new links between Fed and Treasury. Under the Treasury's Supplementary Financing Program (SFP) that was announced on September 17, 2008 as a "temporary" program, the Treasury conducts special bill auctions with the proceeds of these auctions kept in an account at the New York Fed. This SFP account with the Fed, whose balance was $\$ 300$ billion, $\$ 259$ billion, and $\$ 200$ billion at the end of September 2008, December 2008, and April 2009, respectively, bears no interest. Since the Treasury pays interest on the T-bills but receives no interest on the deposit balance in its SFP account, the equivalent of an intra-governmental transfer from Treasury to the Fed is involved. 
Treasury borrowing that puts funds into this account drains reserves that can then be replenished through further lending by the Fed under one of its crisis-relief facilities. In the March 23, 2009 joint statement with the Treasury, the Fed noted that "Treasury has in place a special financing mechanism called the Supplementary Financing Program, which helps the Fed manage its balance sheet. In addition, the Treasury and the Federal Reserve are seeking legislative action to provide additional tools the Federal Reserve can use to sterilize the effects of its lending and securities purchases on the supply of bank reserves.” These tools are likely to include authority for the Federal Reserve to issue its own "sterilization" bonds, thereby freeing it from dependence on the Treasury and enhancing its investment powers without public oversight.

Paying interest on reserves equal to the target federal funds rate or its upper limit also drains ready funds from the financial markets by reconciling depository institutions to holding ever-more excess reserves with the Fed. When interest first started to be paid on required and excess reserves for the maintenance period ending October 15, 2008, the rate was half that of the lowest target federal funds rate during that maintenance period, or $0.75 \%$ compared with $1.50 \%$. The two rates then were equal from the maintenance periods ending November 12 to that ending December 17, falling jointly from 1\% to $0.25 \%$ during this time. While first maintaining the $1 / 4 \%$ rate, effective with the maintenance period beginning December 18, 2008, the Federal Reserve Board returned to the principle of establishing interest rates paid on required reserves and excess reserve balances as it saw fit, rather than by applying an announced formula based on the target federal funds rate. This return from link rules to discretion provides the Fed with an 
additional management tool while raising uncertainty for financial institutions and markets.

I conclude, therefore, that threats to Fed income that could imperil its post-crisis recovery of independence for the time being do not arise from interest payments on reserves held with it by depository institutions or from any margin shrinkage that may accompany the explosive expansion of its balance sheet. Such threats may however arise when that balance sheet needs to contract sharply and interest rates on excess reserves need to be raised sharply in relation to longer rates to keep down inflation. Additional threats could arise from mark-to-market losses, crudely estimated as around $\$ 66.5$ billion, which may reach the Fed from its support actions and LLCs for Citigroup, BAC, Bear Stearns, and AIG in coming years. Because the Fed has gone slow on purchases of agency MBS and longer-term government securities, expected capital losses on such instruments are, as yet, difficult to calculate. All the crude estimates are likely to remain fluid as the Fed keeps repositioning itself with the Treasury. The March 23 “joint statement," for instance, ends with the declaration that "[i]n the longer term and as its authorities permit, the Treasury will seek to remove from the Federal Reserve's balance sheet, or to liquidate, the so-called Maiden Lane facilities made by the Federal Reserve as part of efforts to stabilize systemically critical financial institutions.”

Perhaps more significantly than through any fiscal threats, the Fed's independence is compromised by self-inflicted mission conflicts with its monetary-policy mandate. The Fed is also being forced by the circumstances of the current crisis to coalesce with part of the executive branch, in particular the Treasury. That Department, while offering policy planning support and advice, critically depends on, and properly defers to, presidential 
policy guidance, and, in normal times, pays heed to Congressional intent. Just as important, when the Fed acts as fiscal principal using funds provided by the Treasury charged to U.S. taxpayers or when it uses its own resources withheld from the Treasury to prop up and subsidize financial instruments, institutions and markets as it deems fit, it does so without democratic accountability. Authorizing the Fed to fund its relief and liquidity-sterilization programs by borrowing from capital markets directly rather than through the Treasury would make the Fed less dependent on the Treasury while making the lack of democratic accountability even more glaring. Excessive accumulation and sprawling use of "independent" power tend to attract criticism in democracies.

\section{III.D Borrowed Aggrandizement at the FDIC}

Since the fall of 2008, the FDIC has engaged in occasional shadowboxing with the Treasury over providing assistance and incentives to mortgagors and mortgage servicers to revamp distressed home mortgages and forestall unnecessary foreclosures. Its

Chairman, Sheila Bair, has not always been viewed as a team player, as though team play were mandatory, even for so-called independent agencies, during a crisis. However, the Obama Administration's Homeowner Affordability and Stability Plan adopted on February 18, 2009 to devote up to $\$ 75$ billion of TARP funds to keep people in their mortgaged homes by lowering mortgage payments and balances to shrink default rates and negative equities is close to the outlines of the plan first publicized by the FDIC on November 14, 2008. This FDIC plan was unveiled two days after Secretary Paulson had pronounced the FDIC's mortgagor assistance plan as not qualified for TARP funding because it proposed "spending” rather than "investment." So Bair came out on the right 
side of history. However, such public disagreement is rare and rarely successful for those who go public but are not in the lead, unless they are positioning themselves for retention by an incoming Administration through sharing its disagreement with prior policies.

Here is a lengthy, but telling example of interagency interdependence and manipulation when one of the main, but not the leading, actors develops an urgent need of assistance under crisis conditions. Such a need became evident when FDIC (2009, Table 1-B) reported that the beginning balance in its Deposit Insurance Fund (DIF) had fallen precipitously from $\$ 45$ billion in mid-2008 to $\$ 19$ billion at the end of 2008. If the DIF were to continue to be depleted at this rate, the fund would be exhausted during the second quarter of 2009. In addition, 23\% of all FDIC insured institutions were unprofitable in 2008, and the industry as a whole posted a loss of $\$ 26$ billion in the fourth quarter of that year, the first aggregate loss in 18 years (FDIC, 2009, Tables I-A, II-A).

Even though both the DIF and the client industry were under severe stress, FDIC Chairman Bair insisted publicly that the agency should not use government aid to rebuild the Fund and that it should remain funded not with taxpayer money but with depositinsurance premiums imposed on banks. As reported by Reuters on March 3, 2009, Bair saw no alternative to raising bank fees aggressively to replenish the deposit-insurance fund and restore it to its minimum required level over seven years. On that same date an interim rule was published in the Federal Register (12 CFR Part 327, pp. 9338-9341) that would impose a special assessment of 20 basis points on insured institutions' assessment base (roughly: domestic-office deposits) on June 30, 2009. Because this base was about $\$ 7.5$ trillion at the end of 2008, the yield of this special tax, payable by September 30, 2009, will be around $\$ 15$ billion. 
To meet its obligations, the FDIC has long had standing authority to borrow up to $\$ 30$ billion from the Treasury under a line of credit. However, before spring 2009, it had never done so to cover its insurance losses and publicly continued to claim that it had no intention of doing so. As soon as the FDIC's untimely initiative was announced, Senate Banking, Housing, and Urban Affairs Committee Chairman Christopher Dodd moved on March 6, 2009 to allow the FDIC to borrow up to $\$ 500$ billion from the Treasury until the end of 2010 if the FDIC, Fed, Treasury, and White House agreed, and up to $\$ 100$ billion absent that approval. Dodd reportedly acted in response to urgings from Bair, Bernanke, and Geithner to equip the DIF with means to finance the closure and orderly transfer of control of perhaps even more and larger banks than in 2008 and to initiate the Legacy Loan Program to be revealed later that month. Bair hinted on March 6 that reducing the special assessment, most likely from 20 to $6 \mathrm{bp}$, could be part of the implied deal. ${ }^{34}$ The FDIC was called upon on March 23, 2009 to guarantee loans made to provide up to 85\% debt-financing of the Public-Private Investment Fund(s). As a result the FDIC will become further enmeshed with the Treasury, particularly if these loan guarantees should prove costly because the assets, financed by these loans along with thin slices of public and private equity, were systematically overpriced when purchased by the PPIFs. Sachs (2009) has explained why such overpricing could be egregious if one were to accept his tacit assumption that private price discovery overrules the FDIC's own appraisal of what the assets, collateralizing the loans it guarantees, are worth.

The troika of Treasury, Fed, and FDIC protests too much that taxpayer funds are not about to be called upon without a good prospect of repayment, but funds "invested" in financial institutions and instruments would surely be lost irretrievably should the FDIC 
and the Fed need to be bailed out of costly commitments or have loans forgiven by the Treasury. A unitary government thus turns out to be fiscally and programmatically misleading in a crisis. Things are not as they are made to appear, or at least are not likely to stay that way. Ostensibly to avoid upsetting "the markets" or "confusing” investors and undermining confidence, legislative leaders feel pressured to go along with official misrepresentations. They tend to hold off on any detailed congressional investigations, and refrain, for the duration of the crisis, from developing legislative initiatives that are not welcome in the executive branch. With such Congressional deference, unbridled leadership falls to the executive.

\section{III.E Expansive Use of Emergency Powers by the Treasury, Fed, and FDIC}

The Treasury’s original September 21, 2008 3-page proposal of a \$700-billion TARPlike program that was presented for the Congress to pass in a hurry and with no questions later to be asked has become emblematic of excessive arrogation of power by the executive branch in the critical phase of the financial crisis. Although Congress did not accept this proposal, Congress has been discouraged from becoming active at every turn as though financial-crisis resolution were a matter to be left entirely to the discretion of the executive branch. Such an attitude bodes ill for regulatory reform and due deliberation down the road.

Turning to the Fed, the public mission of the Federal Reserve Board of Governors is “to foster the stability, integrity, and efficiency of the nation’s monetary, financial, and payment systems so as to promote optimal macroeconomic performance.” Thus protecting and -- having failed in that -- restoring the stability of the financial system is 
the Fed's business. Much of the authority used by the Federal Reserve in that regard, starting with the collateralized loan to investment bank Bear Stearns on March 14, 2008, ten days before its assisted acquisition by JP Morgan Chase, has been based on Section 13(3) of the Federal Reserve Act. That section confers temporary emergency powers on the Fed under specified conditions. ${ }^{35}$ As Bernanke (2009a) discusses in some detail, this Section was added to the Act in 1932 to give the Federal Reserve flexibility to respond to emergency conditions by lending to nonbank entities in "unusual and exigent circumstances" and when the borrower is "unable to secure adequate credit accommodation from other banking institutions”.

Prior to March 2008, credit had not been extended under this authority since the 1930s, and the Fed had stuck to its traditional roles of being the lender and liquidity provider of last resort to depository institutions only. From September 2008 on, the Fed stretched and broadened the application of Section 13(3). It continued trying to stabilize systemically important non-depository financial institutions and broker-dealers and also extended its stabilization efforts to securitized credit markets and markets for particular financing instruments throughout the economy. To support its loans to and investments in the private sector, it attracted deposits (in the form of interest-bearing excess reserves of depository institutions) much like an ordinary wholesale bank that relies on borrowing federal funds from other banks.

The FDIC likewise remarkably expanded its emergency powers and activities. In October 2008 it used the "systemic risk exception” clause of the Federal Deposit Insurance Corporation Improvement Act (FDICIA) of 1991 to justify instituting the Temporary Liquidity Guarantee Program (TLGP). The program has two primary 
components: (i) the Debt Guarantee Program, by which the FDIC will guarantee the payment of certain newly-issued senior unsecured debt of insured institutions for up to three years, and (ii) the Transaction Account Guarantee Program, by which the FDIC will guarantee certain non-interest-bearing transaction accounts (of business). Here is the background: In FDICIA, Congress statutorily mandated a new policy for the resolution of failing banks and thrifts under which the FDIC is required to choose the "least costly" resolution method that minimizes expenditures for its deposit-insurance fund. However, the FDIC may bypass the least-cost method if it would have serious adverse effects on economic conditions or financial stability and if bypassing the least-cost method would avoid or mitigate such adverse effects.

The reason that the TLGP could qualify for the systemic risk exception is that it would help reduce the macro-prudential risk that would arise from an unusually large number of FDIC-insured institutions becoming illiquid or insolvent in a financial crisis around the same time. This situation would have adverse effects on economic activity and financial stability. Prior to the November 21, 2008 approval by the FDIC Board of the TLGP Final Rule, the FDIC had cited the "systemic risk exception" for the very first time in late September in conjunction with facilitating the sale of Wachovia Corporation's assets to Citigroup, a sale that did not go through. ${ }^{36}$ Wachovia was one of the largest commercial banks in the United States. It was finally acquired by Wells Fargo without government assistance other than that provided, initially covertly, through IRS notice 2008-83, as noted in Section I of this paper. By March 31, 2009, debt outstanding that was guaranteed under the TLGP had reached $\$ 336$ billion, or 44\% of the program’s cap of $\$ 769$ billion. Among the TLGP beneficiaries are not only FDIC-insured depository 
institutions but also large holding companies and investment banks like Goldman Sachs which own a depository institution. Although guarantee fees must be paid, the full cost of FDIC-guaranteed debt usually is considerably lower than that of any non-guaranteed debt issued by the same companies, and lower still than what the cost of non-guaranteed debt would be if TLGP had not been introduced as an option.

As in the case of the Treasury and the Fed, the crisis prompted the FDIC to assert extraordinary "emergency" or "exceptional” powers that were new, broad, and likely to linger even though they are supposed to be temporary and difficult to invoke. ${ }^{37}$ The FDIC's dependence on the Treasury's budget support and authorizations was much increased. In addition, as for the Fed, there was a quantum leap in the scale of its activities. One difference is that the FDIC's vastly expanded loan guarantee programs for financial institutions may be difficult to scale back politically on account of lobbying for low-cost funds by the client industry.

\section{Summary, Evaluation, and Prospective Bailout Legacies}

For evaluating the quality of policy responses to a major financial crisis, the surprise factor is important. If such a crisis fell upon a country entirely unexpectedly, there would be no time to devise and implement a coherent strategy to defuse it. The whole truth of the moment, like merciless application of fair-value accounting involving mark-tomarket, could be too much to share in a panic. This burden is what the financial industry complained of before Congress obliged it in mid-March 2009 by pressuring the Financial Accounting Standards Board (FASB) to water-down the mark-to-market rigor of fair- 
value rules. FASB did so on April 2, 2009 even though there were some signs that the financial crisis was already abating.

In fact, the first major global financial crisis of the $21^{\text {st }}$ century did not break out suddenly in full force. A useful "timeline”, with links to the most important news releases and official program-announcement documents associated with the financial crisis, starts with an entry for February 2007. ${ }^{38}$ It since has been generally agreed (see, for instance, Baily, Litan, and Johnson, 2008; Cecchetti, 2009) that in summer (or by August) 2007, the global financial markets found themselves facing a potential financial crisis. Bernanke has taken credit repeatedly for the Fed's responding quickly and forcefully by starting to cut the target federal funds rate from September 2007 on. Bernanke (2009b) has also conceded that the financial crisis intensified significantly over a year later, in September and October 2008, nonetheless.

The very fact that the crisis appeared to be building slowly had led to widespread speculation in the summer of 2008 that it would soon be abating. There is no indication from professional forecasts that the intensification phase that started in September 2008 was widely predicted. ${ }^{39}$ When failures of major financial institutions that could potentially be systemic suddenly became a clear and present danger, they triggered hurriedly improvised and erratic emergency responses from that month on. No resolution strategy for nonbank financial institutions was in place that laid down clear rules and assigned precise areas of responsibility to each of the federal banking agencies and to the U.S. Treasury in the event of a major crisis. It took Geithner and Bernanke until March 26, 2009 to offer concrete first thoughts on a new regulatory agenda for financial markets and instruments and an orderly resolution strategy for systemically significant financial 
institutions. Nevertheless, as happens in states of emergency not associated with revolution, existing executive powers were strengthened and tightened almost immediately when the crisis became acute.

Pressures for prompt actions to relieve the crisis pose an intertemporal dilemma: Those rescue actions that are easiest and most effective to implement in the short run, such as issuing blanket asset guarantees, tend to become counterproductive and costly in the long run. As Ergungor and Cherny (2009) have illustrated, historically these long-run costs are not only the fiscal legacies of the earlier bailouts but incentive distortions that lead to renewed underpricing of risk and more moral hazard in future calculations. What may be stabilizing in the short run -- such as arranging for the takeover of large failing financial institutions by even bigger institutions -- may be destabilizing in the long run. This counterproductive situation applies, for instance, if reducing exposure to financial institutions that are too big to fail is the long-term goal, as Bernanke (2009c) has considered. Annihilating risk premiums in mortgage finance is another initially sweet and ultimately disastrous measure that helps housing to recover while laying the groundwork for a follow-on crisis down the road.

The financial crisis that started in mid-September 2008 and did not begin to let up until April 2009 brought significant changes in the structure of U.S. governance. Though installed for the crisis, some of these changes may persist for many years.

1. The deliberative and law-making powers of the legislative branch, the U.S. Congress, were bypassed or subordinated to emergency decision-making by the executive branch. Congressional participation was largely reduced to enacting what was asked for by the executive after some brief stalling and 
ineffectual second-guessing. Statutorily independent federal banking agencies like the Fed and the FDIC broadly interpreted their emergency or exceptional powers to engage in an unprecedented expansion of the range and volume of their activities. The Treasury contracted, and repeatedly re-contracted, with private parties to whom it provided loans or equity injections on terms that it felt free to set and then to modify and soften without reference to any clear and consistently applied rule or standard. The crisis thus led to centralization of power within the executive branch of the U.S. government and a vast enhancement of the discretionary powers of the key executive agencies charged with confronting the crisis.

2. A core group of executive agencies, in particular, the Federal Reserve and the FDIC, collaborated with the U.S. Department of the Treasury in joint crisis management. All three issued new forms of guarantees and shared in the resulting risks. For this and other risky ventures, the Fed and the FDIC needed, and received, both explicit and implicit backstopping by the Treasury, jeopardizing their fiscal independence. With or without direct Treasury support, the Fed and FDIC clearly took on fiscal functions in directing the flow of bailout funds and individual subsidies irrespective of whether these were labeled "investments." Both of these federal banking agencies developed new non-bank clients and vast interventions in financial markets that went far beyond simply helping intermediation systems to recover. Through establishment of its Supplementary Financing Program account at the Fed, the Treasury also helped with the Fed's own liquidity management, blurring the 
lines of responsibility between the two. The result was centralization of decision-making within the executive branch as major initiatives in crisis management were announced in joint statements worked out by Treasury, the Fed, and FDIC for clearance by the Office of the President. Joint Congressional testimony, often pairing Geithner with Bernanke, also became common, with both speaking for the Administration in unison.

In sum, shifting power to the executive branch of the Federal Government, and expanding its powers and room for discretion relative to the other two branches of government, and absolutely, was the first noticeable effect of entering the emergency phase of the 2007-2009 financial crisis. The second effect was that jurisdictional boundaries between government agencies quickly became blurred as the crisis hitched them together. The separation of mandates between independent agencies and cabinet departments tended to be set aside in the process of centralizing crisis management powers and resources within the executive branch.

\section{IV.A Evaluation}

Although this paper does not attempt any systematic performance evaluation, ${ }^{40}$ it contains several indications that policy execution was haphazard, time-inconsistent, and stop-start in its nature in several of the instances cited and explored at some length. There was a tendency for the government selectively to modify its relief contracts with private parties for the benefit of the latter. This behavior on the part of the government created perverse incentives because of soft budget constraints, especially for systemically significant financial institutions: The weakest among them could readily agree to 
whatever loss participation and "punitive" interest and dividend rates the government imposed knowing that failure to deliver on their obligations would have to be papered over with even more government aid. Contract erosion in favor of private parties also added to uncertainty through the political risk attending implicit government insurance. As the intense phase of the crisis progressed, Paulson's ringing mantra about investing in private companies on terms that protect the taxpayers began to ring hollow.

Months before there were indications that the relief program was getting adequately organized, the three key agencies involved, Treasury, the Fed, and the FDIC, had already issued broad guarantees in different areas. These guarantees have proved helpful and cost-effective in some areas such as for restoring (i) assured access to borrowed liquid funds and (ii) the functioning of markets for short-term claims -- such as commercial paper and money market mutual fund shares -- that normally are highly liquid. However, the risk is high that some of these guarantees, like the TLGF, have been granted for too long ahead to start with and then even extended so that they impede a return to unsubsidized financing conditions. Even longer term government guarantees or investment partnerships with private parties may not be cost-effective for the nation's taxpayers at all. They involve hard-to-value distressed long-term securities and claims, or federally guaranteed loans collateralized by such legacy assets. The reason is that private parties, when given the opportunity and enough time to take big gambles with proportionately small equity stakes invariably succeed in skimming off the fat under asymmetric public-private constructions euphemistically called "partnerships".

Making haste in showering help on private parties led to neglect of critical preparations and to unnecessary waste in other respects. Thus it took almost half a year 
from the onset of the most intense stage of the crisis for government agencies to decide that they needed to stress test the largest financial institutions to whom they had already extended all manner of support. Only in late February 2009 did the lead agencies express a need to learn independently more about the extent of the problem they were facing. So they instituted a procedure that would let them ascertain the risks to the capital adequacy of the institutions to which the government was exposed before committing further funds from what remained in the second half of the TARP. Findings started to be leaked weeks before the eventual May 7 release date of the stress-test results that appear to have been vetted by the Fed with the 19 institutions tested.

\section{IV.B Economic and Political Legacies}

Now that "troubled" or "toxic" assets have been renamed "legacy" assets, the time has come to try to anticipate the legacies of the current bailout programs. Greatly increased levels of government debt and of future budget deficits, though first among the macroeconomic legacies with political implications, will not be covered here. The benefit of this exclusion is that it allows an undivided focus on the adverse long-term side effects of specific crisis-management operations rather their total budget impact.

- Treasury (also the Fed, and the FDIC): Bailouts have been offered with changing rationales and coverage on ever-changing terms and conditions tailormade for individual institutions. Treasury and Fed have implemented recapitalization and public-private asset-pool and investment partnership models and contracts that were based on false analogies with private finance. These models, if not constructed for the government on the principle of "heads you win, 
tails I lose” in the first place, failed to take account of the fact that for the privatesector institutions to share upside risk with the government is hard and credible, but sharing downside risk is soft and not credible when private-sector institutions are to be rescued at any price. Furthermore, by making low-interest non-recourse loans or offering inexpensive loan guarantees, the government takes on all the risks of debt finance without adequate compensation. It shares in the upside potential only in proportion to the equity finance is has provided to public-private investment funds. The benefits inherent in any implicitly subsidized government, or government-guaranteed, debt financing thus partly redound to the private equity partner and are not fully recouped by the government. Viewed as an experimental search process, the huge expansion of the government's active crisis management toolkit thus has not yielded solid results or led to the discovery of commendable new management models. The concern is, that the huge expansion of the active toolkit will remain nonetheless.

- Fed: Mission conflicts arise from becoming a major investor in fixed-rate longterm instruments and trying to twist interest-rate structures through portfolio interventions. Once the Fed has loaded up on agency securities and longer-term Treasuries bearing abnormally-low interest rates, its fiscal health and independence will be in jeopardy if there is a need to raise the target federal funds rate aggressively in coming years to counter excessive depreciation of the dollar or other inflationary threats. There is at least one other dilemma. To the extent the Fed generates positive cash-flow from some of the financial businesses it has chosen to enter, its dependence on the Treasury is reduced. But the Fed thereby 
also gains unchecked powers of cross-subsidization among its several new facilities and resource-allocation programs for specific institutions and markets without any but the most cursory ex-post-facto Congressional review. Such a review does not afford meaningful opportunity for democratic participation.

- FDIC: Its active, and eventually costly, modification of distressed mortgage loans, that started after its July 17, 2008 takeover and conversion of IndyMac into a Bridge Bank (IndyMac Federal) that has since been privatized, ${ }^{41}$ may fit the systemic risk exception but not its core mission. That mission is to maintain the stability and public confidence in the nation's financial system by insuring deposits, examining and supervising financial institutions, and managing receiverships. The TLGP for the issuance of short- and medium-term bank debt guaranteed for up to three years is now scheduled to start being wound down later this year unless extended further. However, a new program to guarantee the debts of public-private investment partnerships acquiring pools of long-term legacy loans and other assets again takes the FDIC far beyond dealing with FDIC-insured institutions and set it up for having to bear a net increase in uncompensated risk. The excess costs of these guarantees may create lasting dependency on the Treasury.

- Fannie Mae and Freddie Mac: The destruction of the private home-mortgage market will proceed further through operating Fannie Mae and Freddie Mac as government utilities for subsidized mortgage finance. Having already agreed to make first $\$ 100$ and then $\$ 200$ billion in subsidies dressed up as preferred equity "investments" available to each of the two institutions, it is clear that the Treasury 
will have to recapitalize Fannie Mae and Freddie Mac on an on-going basis to help them cover their structural operating deficits. Treasury (2009b) has made quite clear that its way of "supporting low mortgage rates by strengthening confidence in Fannie Mae and Freddie Mac" is to "provide forward-looking confidence" that increased public funding will be available "to enable Fannie Mae and Freddie Mac to carry out ambitious efforts to ensure mortgage affordability.” The multi-billion quarterly losses of these institutions will increase greatly if short rates, and hence their cost of funds mostly in the 1- to 5-year maturity range, should rise.

Extending the full faith and credit of the U.S. government to agency-MBS subsidizes mortgage credit in a way that makes "originate and hold" unprofitable for private mortgage lenders. Fannie and Freddie together are on a path expected by the end of 2010 to lead to losses of $\$ 200$ billion to be paid for by the Treasury out of $\$ 400$ billion set aside for that purpose. As Rob Cox and Richard Beales (NYT, May 11, 2009, p. B2) have concluded, Fannie and Freddie are the real zombies. They deserve to be delisted and unambiguously placed on the government's balance sheet to confront officials through the budget process with what they have done.

The U.S. tax system already favors mortgage-financed homeownership. It is not clear why residential-capital formation should be subsidized even more by the Fed and the Treasury's attempting to depress fixed mortgage rates artificially by a variety of means below the level needed to allow private institutions to originate and hold home mortgages directly or as collateral for non-agency MBS. Making 
residential mortgage financing a function that is intermediated and ultimately financed with the full faith and credit of the federal government distorts the allocation of private investment and detracts from long-term economic growth.

It is clear therefore that the programs hurriedly adopted in the depth of the financial crisis from September 2008 to March 2009 will not only have lasting political side effects on U.S. governance and political organization, but also leave economic legacies that will prove difficult to live down.

Acknowledgement: I am grateful to Michael K. Ulan for contributing a number of improvements to a previous draft. 
Table 1. Bush Administration TARP Fund Commitments to Corporations

\begin{tabular}{|c|c|c|c|c|c|c|}
\hline \multirow[b]{2}{*}{$\begin{array}{l}\text { Company } \\
\text { (date of agreement) }\end{array}$} & \multirow{2}{*}{$\begin{array}{c}\text { Closing } \\
\text { Stock Price } \\
\text { 08-29-8/02-27-9 } \\
\text { (\$, on date) }\end{array}$} & \multicolumn{2}{|c|}{$\underline{10-Y e a r ~ W a r r a n t s ~}$} & \multicolumn{2}{|c|}{ _Preferred Equity } & $\begin{array}{l}\underline{\text { Total }} \\
\text { Outlay }\end{array}$ \\
\hline & & $\begin{array}{l}\text { Number } \\
\text { of Shares } \\
\text { (million) }\end{array}$ & $\begin{array}{c}\text { Exerci } \\
\text { Price } \\
(\$)\end{array}$ & $\begin{array}{c}\text { Cost }= \\
\text { Liqu Value } \\
\text { (\$ billion) }\end{array}$ & $\begin{array}{c}\text { Coupon } \\
\text { Rate } \\
(\%)\end{array}$ & $\underline{\text { Outlay }}$ \\
\hline AIG & 21.49/0.42 & & & & & \\
\hline (11/11/2008) & 1.77 & 53.8 & 2.5 & 40 & 10 & 40 \\
\hline Bankof America & 31.14/3.95 & & & & & \\
\hline (10/26/2008) & 23.02 & 73.08 & 30.79 & 15 & 5 then 9 & 15 \\
\hline (01/09/2009) & 12.99 & 48.72 & 30.79 & 10 & 5 then 9 & 10 \\
\hline (01/16/2009) & 8.32 & 150.38 & 13.3 & 20 & 8 & 20 \\
\hline Citigroup & $18.99 / 1.50$ & & & & & \\
\hline (10/26/2008) & 13.41 & 210.08 & 17.85 & 25 & 5 then 9 & 25 \\
\hline (12/31/2008) & 6.71 & 188.5 & 10.61 & 20 & 8 & 20 \\
\hline (01/16/2009) & 3.50 & 66.5 & 10.61 & 7 & 8 & 7 \\
\hline General Motors & $10.00 / 2.21$ & & & & & \\
\hline (12/29/2008) Loan & 3.60 & 122.4 & 3.57 & 4+1GMAC & LIBOR+300 & 5 \\
\hline (01/16/2009) Loan & 3.93 & & & 5.4 & BP, 3Yr. & 5.4 \\
\hline (02/17/2009) Loan & 2.18 & & & 4 & $5 \mathrm{~min}$. & 4 \\
\hline (12/29/2008) GMAC & 8.22 & & & 5 & 8 & 5 \\
\hline Goldman Sachs & 163.97/88.62 & & & & & \\
\hline$(10 / 26 / 2008)$ & 93.57 & 12.21 & 122.9 & 10 & 5 then 9 & 10 \\
\hline JP Morgan Chase & $38.49 / 22.85$ & & & & & \\
\hline$(10 / 26 / 2008)$ & 37.60 & 88.4 & 42.42 & 25 & 5 then 9 & 25 \\
\hline Morgan Stanley & $40.83 / 19.54$ & & & & & \\
\hline$(10 / 26 / 2008)$ & 15.20 & 65.25 & 22.99 & 10 & 5 then 9 & 10 \\
\hline Wells Fargo & $30.27 / 13.65$ & & & & & \\
\hline$(10 / 26 / 2008)$ & 34.46 & 110.26 & 34.01 & 25 & 5 then 9 & 25 \\
\hline Other to $01 / 19 / 09^{*}$ & & & & & & 153.4 \\
\hline Total as of $01 / 19 / 09$ & & & & & & 379.8 \\
\hline
\end{tabular}

* This "other" amount, committed by the last full day of the Bush Administration, consists of

(a) $\$ 5$ billon allocated to 2 smallest of the 9 (after Merrill Lynch's absorption by BAC:8) big banks,

(b) $\$ 70.6$ billion allocated and $\$ 52.4$ billion committed to all other banks under the CPP,

(c) $\$ 4$ billion loaned to Chrysler and $\$ 1.4$ billion to Chrysler Financial Corporation under the AIFP, (d) \$20 billion as a backstop for losses under the Fed's Term-Asset Backed S. Loan Facility, TALF. Sources: U.S. Department of the Treasury, Section 105(a) Troubled Asset Relief Program:

Report to Congress (for consecutive periods), also Treasury Press Releases and Term Sheets. 


\section{References}

Baily, Martin Neil, Robert E. Litan, and Matthew S. Johnson. 2008. "The Origins of the Financial Crisis,” Fixing Finance Series - Paper 3, Washington, D.C.: Brookings Institution, November.

Bernanke, Ben S. 2009. “The Crisis and the Policy Response,” Stamp Lecture, London School of Economics, London, England, January 13. http://www.federalreserve.gov/newsevents/speech/bernanke20090113a.htm .

Bernanke, Ben S. 2009a. "Federal Reserve Programs to Strengthen Credit Markets and the Economy,” Testimony before the Committee on Financial Services, U.S. House of Representatives, Washington, D.C., February 10 http://federalreserve.gov/newsevents/testimony/bernanke20090210a.htm .

Bernanke, Ben S. 2009b. “Semiannual Monetary Policy Report to the Congress,” Washington, D.C., February 24 http://federalreserve.gov/newsevents/testimony/bernanke20090224a.htm .

Bernanke, Ben S. 2009c. "Financial Reform to Address Systemic Risk," Speech at the Council on Foreign Relations, Washington, D.C., March 10.

Board of Governors (of the Federal Reserve System). 2008. Annual Report 2007.

Board of Governors. 2009. “The Federal Reserve Banks: Combined Financial Statements as of and for the Years Ended December 31, 2008 and 2007, and Report of Independent Auditors,” April 20.

Board of Governors. 2009a. “The Supervisory Capital Assessment Program: Design and Implementation,” April 24. 
Cecchetti, Stephen G. 2009. “ Crisis and Responses: The Federal Reserve in the Early Stages of the Financial Crisis,” Journal of Economic Perspectives 23(1), Winter: 5175.

CBO (Congressional Budget Office). 2007. "How CBO Projects the Real Rate of Interest on 10-Year Treasury Notes,” Background Paper, December.

CBO. 2009. “The Troubled Asset Relief Program: Report on Transactions Through December 31, 2008,” A CBO Report, January.

COP (Congressional Oversight Panel). 2009. February Oversight Report: Valuing Treasury’s Acquisitions, February 6. http://cop.senate.gov/documents/cop-020609report.pdf .

Elliott, Douglas J. 2009. “Measuring the Cost of the TARP,” Initiatives on Business and Public Policy at Brookings, January 23.

Ergungor, Q. Emre and Kent Cherny. 2009. “Effective Practices in Crisis Resolution and the Case of Sweden,” Federal Reserve Bank of Cleveland Economic Commentary, February.

FDIC (Federal Deposit Insurance Corporation). 2008. “12 CFR Part 370: Temporary Liquidity Guarantee Program; Final Rule,” Federal Register, 73(229): 72244-72273, November 26.

FDIC. 2009. Quarterly Banking Profile, Fourth Quarter 2008.

GAO (United States Government Accountability Office). 2008. Troubled Asset Relief Program: Additional Actions Needed to Better Ensure Integrity, Accountability, and Transparency., GAO-09-161, December. 
GAO. 2009. Federal Financial Assistance: Preliminary Observations on Assistance Provided to AIG, GAO-09-490T, March.

GAO. 2009a. Troubled Asset Relief Program: March 2009 Status of Efforts to Address Transparency and Accountability Issues, GAO-09-504, March.

Geithner, Timothy. 2009. "Secretary Geithner Introduces Financial Stability Plan,” February 10. http://www.ustreas.gov/press/releases/tg18.htm (includes link to Fact Sheet, Financial Stability Plan).

Hafer, Rik W. 2005. The Federal Reserve System: an Encyclopedia, Westport, CT: Greenwood Publishing Group.

Hall, Robert E. 2007. “How Much Do We Understand about the Modern Recession?” Brookings Papers on Economic Activity, 2: 13-28.

Higgs, Robert. 1987. Crisis and Leviathan: Critical Episodes in the Growth of American Government. New York: Oxford University Press, 1987.

Kashkari, Neel. 2009. "Interim Assistant Secretary for Financial Stability Neel Kashkari Review of the Financial Market Crisis and the Troubled Asset Relief Program,” January 13. http://www.ustreas.gov/press/releases/hp1349.htm .

Paulson, Henry M. 2008. Testimony of Secretary Henry M. Paulson, Jr., before the House Committee on Financial Services,” Treasury Press Release HP-1279, November 18. http://www.treasury.gov/press/releases/hp1279.htm .

Paulson, Henry M. 2009. "Remarks by Treasury Secretary Henry M. Paulson, Jr. on The Role of the GSEs in Supporting the Housing Recovery before the Economic Club of Washington,” January 7. http://www.ustreas.gov/press/releases/hp1345.htm . 
Roubini, Nouriel. 2008. “How Authorization to Recapitalize Banks via Public Capital

Injections was Introduced - indirectly through the back door - into the TARP

Legislation,” Global Economic Monitor, October 9.

Sachs, Jeffrey. 2009. “Obama’s Bank Plan Could Rob the Taxpayers,” Financial Times, March 25.

Sengupta, Rajdeep, and Yu Man Tam. 2008. “The LIBOR-OIS Spread as a

Summary Indicator,” Federal Reserve Bank of St. Louis Economic Synopses, No. 25.

Sims, Christopher A. 2008. "Fiscal/Monetary Coordination in a Time of Crisis,” unpublished, December 17.

Smith, Yves. 2009. “Fed Rescue Programs: No Exit?” RGE Monitor, March 23.

U.S. Department of the Treasury. 2009. “U.S. Government Finalizes Terms of Citi

Guarantee Announced in November,” Press Release hp-1358, January 16.

U.S. Department of the Treasury. 2009a. Fifth Tranche Report to Congress, February 6.

U.S. Department of the Treasury. 2009b. “Making Home Affordable: Updated Detailed

Program Description.” Washington, D.C., March 4.

Wallison, Peter J., and Charles W. Calomiris. 2008. The Last Trillion-Dollar

Commmitment: The Destruction of Fannie Mae and Freddie Mac. Washington, D.C.:

American Enterprise Institute.

\section{Endnotes}

\footnotetext{
${ }^{1}$ Standing shoulder to shoulder is a common aspiration and coping mechanism for those involved in managing a major crisis. For instance, the front page of the New York Times of May 2, 2009 quotes Ron Gettelfinger, the United Auto Workers' president, as having said this the previous day: "It's not like we are going into this bankruptcy fighting with Chrysler and Fiat and the U.S. Treasury. We're going in there in lockstep to put our agreements in place.”

2 The authority of the Treasury to use capital injections had to be "clarified" on the House floor prior to passage of ESSA during a colloquy between Representative Moran and the Chairman of the House Financial Services Committee, Frank, a colloquy held precisely because no such authority could be found in ESSA.
} 
3 The complex provisions and the way their application was changed by IRS Notice 2008-83 are clearly explained in Thomas Wechter and Colleen Feeney Romero, “The IRS Bailout of the Bailout,” December 11, 2008, http://www.cpa2biz.com/browse/print_articles_landing.jsp . In a related matter, net operating carryback normally is limited to the preceding two years, and carryforward to up to 20 years following the loss year. The American Recovery and Reinvestment Act of 2009, popularly referred to as the "stimulus" bill, increased the loss carryback period for 2008 net operating losses to 5 years for small businesses with annual revenue of no more than $\$ 15$ million.

${ }^{4}$ The operative sentence in the change in the tax rule invented by the IRS on September 30, 2009 is:"For purposes of section 382(h), any deduction properly allowed after an ownership change to a bank with respect to losses on loans or bad debts shall not be treated as a built-in loss or a deduction that is attributable to periods before the change date.”

${ }^{5}$ On September 29, 2008, Citigroup agreed to take over Wachovia's banking operations for $\$ 2.2$ billion. The Citigroup offer had come with a backstop from the FDIC, which would cover any losses on Wachovia’s $\$ 300$-billion loan portfolio beyond the first $\$ 42$ billion. Because the competing Wells Fargo offer that materialized immediately afterwards did not involve FDIC assistance, it was represented as having the virtue of not relying on government aid. In fact, IRS notice 2008-83 conveyed about $\$ 20$ billion of such aid to Wells Fargo. IRS reversible notices that can be relied upon legally -- until further clarification is issued that withdraws them -- are ideally suited to benefit individual companies through temporary suspensions of existing laws and are, hence, objectionable.

${ }^{6}$ Rather than amend ESSA by this Act as intended when it was introduced in the House of Representatives on January 9, 2009, the Senate on January 15 cleared the way for the Obama Administration later to access the second half of the $\$ 700$ billion financial rescue (TARP) commitment by defeating a "resolution of disapproval" designed to block release of the money.

${ }^{7}$ On March 25, 2009, the Treasury released CPP repurchase instructions for public and private companies that received such capital injections from the Treasury. If a public company repurchases $100 \%$ of the Treasury's preferred stock, it is also given 15 days to either repurchase the warrant for common stock at fair-market value, or to issue a replacement warrant that does not contain the "adjustment" authority to reduce by up to half the number of shares covered by the warrant in the event of a qualified equity offering. Once a private company repurchases $100 \%$ of the primary preferred shares (the ones initially paying $5 \%$ per annum) it can also repurchase up to $100 \%$ of the warrant preferred shares (paying $9 \%$ ) that were issued by the private companies in lieu of stock warrants. The deadline requirements for the repurchase of warrants and the expectation that the warrants would be valued by a recognized scientific method were not met. The very first publicly traded company that repurchased both the preferred equity and the warrants issued to the Treasury -- a regional bank, Old National Bancorp (ONB), headquartered in Evansville, IN -- did so on March 31 and May 11, 2009, respectively. Furthermore, at a stock price of around $\$ 13$ per share, and an exercise price of $\$ 18.45$, and with high volatility and an interest rate on 10 year Treasuries of about 3\%, the Treasury and ONB eventually agreed on a price of $\$ 1.476$ per warrant for the 813,008 10-year warrants that had been issued to the Treasury, a price greatly below what any reasonable application of the Black-Scholes formula would yield. For instance, Institutional Risk Analytics IRA Corporate Monitor on May 15, 2009 reported one-year volatility of $81.7 \%$ for ONB's common equity. Multiplying by the squareroot of 10 , the corresponding 10 -year volatility is $258.4 \%$. Using these input data and ignoring dividends then yields a warrant ("call”) price of $\$ 12.99$ with the 10 -year volatility and $\$ 9.06$ if the one-year volatility value is used for looking to a calmer 10 years ahead. These results are from the Black-Scholes calculator at http://www.blobek.com/black-scholes.html . The amount paid by the company to repurchase the warrants, $\$ 1.2$ million, which is exactly equal to $8 \%$ of the $\$ 15$ million exercise value of the warrants, thus was arrived at through extended negotiations between the Treasury and ONB and not by application of any recognized valuation formula. For the government to strike discretionary deals with private companies in such situations inevitably invites corruption and lawsuits charging unequal treatment by companies receiving what they view as less concessionary deals.

${ }^{8}$ Possibly objectionable standards imposed on institutions participating in the voluntary CPP program are listed in the 10/14/2008 Treasury Release HP-1207: http://www.treas.gov/press/releases/hp1207.htm .

9 The practicality of this suggestion may be doubted since an appropriate "crisis" range of the index must be determined ex ante. This may be difficult to do for lack of relevant experience. For instance, on April 16, 2009, the i-shares Dow Jones U.S. Financials opened at $\$ 39.91$, having had a 52-week high of $\$ 94.00$ and a low of $\$ 23.15$. 
10 See http://www.federalreserve.gov/newsevents/press/bcreg/20090223a.htm .

11 The exercise price of the warrants issued with that portion was $\$ 17.85$.

12 A simple European-style Black-Scholes option value calculator for stocks paying no dividends shows that, even at Citigroup's closing price of $\$ 1.50$ on that day shown in Table 1, warrants with exercise prices of $\$ 17.85$ or $\$ 10.61$, both far out of the money, would be worth $\$ 0.44$ and $\$ 0.58$ respectively, assuming an interest rate of $5 \%$, a panic level of volatility of 60 , and a time to expiration of 3650 days.

13 The Treasury Department's Office of the Controller of the Currency (OCC) charters, regulates, and licenses all national banks, and the Office of Thrift Supervision (OTS), also an agency of the Treasury, does the same for federal thrifts (savings and savings and loan associations). These are the other two federal banking agencies involved.

${ }^{14}$ Other forms of intra-governmental agreements not discussed in the text were spurred by the financial crisis. One example is the July 7, 2008 agreement between the Securities and Exchange Commission (SEC) and the Fed to share information and to cooperate regarding the activities of bank holding companies and "Consolidated Supervised Entities” that own securities firms, where the SEC is the primary supervisor. SEC Chairman Cox noted at the time that the dividing lines between commercial and investment banking had become blurred, and the interconnectedness of mortgage and lending markets, credit derivatives, securitizations, and counterparty relationships required the U.S. government to adopt a more coherent and coordinated approach.

15 The FDIC currently charges a fee of 1 percentage point of the amount of debt sold under the TLGP. However, is announced on March 13 that it wanted to add a fee of 25 basis points (bp) for banks and 50bp for bank holding companies to help replenish the FDIC's deposit insurance fund discussed in Section II.C.

${ }^{16}$ There were also no inspections by Japanese supervisory authorities prior to the first capital injection into banks that happened in the Spring of 1998, six years after the outbreak of Japan's last severe financial and economic crisis in 1992. Because this first injection was not commensurate with the size of the banks' problem and its distribution by institutions, it proved largely futile.

17 This information is contained in U.S. Department of the Treasury (2009a, p. 3).

${ }^{18}$ Because the 3-month OIS rate is also used in the Commercial Paper Funding Facility (CPFF) on loans to the SPV purchasing the commercial paper (on March 13, 2009 the rate an asset-backed commercial paper was 3-month OIS +300 basis points $=3.25 \%$ ), it needs to be explained. An overnight indexed swap (OIS) is an interest rate swap of a, typically 3-month, OIS fixed-rate security and a floating-rate security. The latter is calculated as the compound annualized rate of return on a rollover investment for three months in overnight funds for which there is a published interest rate, i.e., the effective federal funds rate. The interest rate used in the OIS contract is less risky than the corresponding LIBOR at which banks borrow unsecured funds from other banks in the London wholesale money market (for instance, for a period of three months). The OIS has little exposure to default risk because these contracts involve ex post settlement of the realized interest differential, not any initial cash flow. For this reason the fixed leg of this swap, called the OIS rate, can be viewed as an accurate measure of the effective federal-funds rate and, hence, the Fed's target for that rate. LIBOR, however, which refers to the interest rate on a cash instrument, reflects both credit and liquidity risk. The 3-month LIBOR-OIS Rate Spread thus has been used widely as a measure of the credit and liquidity risks in the financial system. Its level rose from around 10bp before the onset of turmoil in the credit markets in August 2007 to 365bp on October 10, 2008 when the banking crisis had become most intense and widespread. Acknowledgement: This description is based on Sengupta and Tam (2008).

19 In June 2008, brazen until just before the government took it over, AIG leased 800,000 sq. feet at 180 Maiden Lane in the financial district of Lower Manhattan in what was billed as the year's biggest lease deal.

${ }^{20}$ See http://research.stlouisfed.org/fred2/series/WMAIDEN1 or ...2, or ...3.

${ }^{21}$ The Fed announced on May 1, 2009, that the CMBS program would start in June and that a new TALF program for securities backed by insurance-premium finance loans was being initiated to facilitate the flow of credit to small business. The release and the "terms and conditions" sheet for TALF CMBS explain that the maximum maturity of TALF loans was being increased from 3 to 5 years and that the latter would bear a fixed rate of interest 100bp above the 5-year LIBOR swap rate (which was $2.625 \%$ on May 4). See http://www.federalreserve.gov/newsevents/press/monetary/20090501a.htm .

${ }^{22}$ An April 6, 2009 Treasury release providing “updated guidance” on the Legacy Securities PPIP released by the Treasury on March 23 insists that Legacy TALF and Legacy Securities PPIP are separate programs, but then explains that "a qualified investor utilizing Legacy TALF will do so on the same terms 
and conditions as a Legacy Securities PPIP investor utilizing Legacy TALF.” See

http://www.ustreas.gov/press/releases/tg82.htm .

${ }^{23}$ There other examples of networks of mutual reliance involving the Treasury, the Fed, and other parties. For instance, as of February 25, 2009, the Fed held mortgage-backed securities on its balance sheet that were recorded at their face value of $\$ 68.5$ billion, which is the remaining principal balance of the underlying mortgages rather than their market value because timely payment of principal and interest was guaranteed by one of the federal housing agencies. These agencies are Fannie Mae (The Federal National Mortgage Association), Freddie Mac (the Federal Home Loan Mortgage Corporation), and Ginnie Mae (the Government National Mortgage Association). Before Fannie Mae and Freddie Mac were placed under conservatorship on September 7, 2008, only the guarantees of Ginnie Mae had borne the full faith and credit of the U.S. Government. Under conservatorship, the ability of Fannie Mae and Freddie Mac to issue and honor their guarantees is dependent on the Treasury's adequately funding these loss-making government-sponsored enterprises (GSEs). Having become tools of the government in its attempts to revive the housing and mortgage-credit markets and having been assigned undue risk and forbearance responsibilities, Fannie Mae and Freddie Mac are unlikely to be fit for reprivatization; Wallison and Calomiris (2008) and Paulson (2009) have written thoughtfully on this subject.

${ }^{24}$ See U.S. Department of Commerce, Bureau of Economic Analysis, NIPA Table 3.2 Federal Government Current Receipts and Expenditures.

${ }^{25}$ See Board of Governors (2008), Table 9: Statement of Condition of the Federal Reserve Banks; Board of Governors (2009), p. 1.

${ }^{26}$ The Fed indicated that these purchases would be financed through the creation of additional bank reserves although they could equally well be financed by reducing the Fed's holding of Treasury securities as explained below.

27 See Board of Governors (2008), Table 10: Income and Expenses of the Federal Reserve Banks; Board of Governors (2009), p. 2. For 2008 only, the residual identified as "payments to U.S. Treasury as interest on Federal Reserve notes" in the latter source, $\$ 31.7$ billion, does not agree with the $\$ 32.7$ billion identified in the NIPA as the contribution of "Federal Reserve Banks" to Federal taxes on corporate income.

${ }^{28}$ At the end of 2007, the Fed had total deposit liabilities of \$39 billion, including \$21 billion to depository institutions and $\$ 16$ billion to the general account of the U.S. Treasury. Excess reserves at the time were $\$ 2$ billion and total reserves $\$ 43$ billion. According to the Fed's H.4.1 statistical release of February 26, 2009, on February 25, 2009, total deposits with the Fed were $\$ 940$ billion, with $\$ 701$ billion owed to depository institutions, $\$ 3$ billion to foreign official institutions, and $\$ 36$ billion in the general account and $\$ 200$ billion in the Supplementary Financing Program (SFP) account of the U.S. Treasury. On a seasonallyadjusted basis, excess reserves of depository institutions on the latter date were $\$ 673$ billion which is $92.6 \%$ of the total reserves of $\$ 727$ billion. The SFP was started September 17, 2008 in effect to let the U.S. Treasury borrow on behalf of the Fed, rather than let the Fed issue its own bonds directly, to reduce the liquidity of depository institutions. Even so, the Fed had reduced its holdings of U.S. Treasury securities by over one-third since the end of 2007 for essentially the same purpose of liquidity control.

${ }^{29}$ Hence, I disagree with Sims' (2008, p. 5) assessment in the present context that "with interest being paid on reserves, the flow of seigniorage will be smaller, and could become negative." If the income of the Fed should become negative, it will not be for this reason. Sims also ignores that the Treasury's Supplementary Financing Program (SFP) account with the Fed, whose balances were \$300, \$259, and \$200 billion at the end of September 2008, December 2008, and February-April 2009, respectively, bears no interest. For comparison, the non-interest bearing total reserves outstanding at the end of 2007 amounted to only $\$ 43$ billion. While the SFP is supposed to be temporary, its remaining expected life is currently unknown. ${ }^{30}$ When adding $\$ 750$ billion to its $\$ 500$-billion commitment to purchase “agency” MBS (guaranteed as to the timely payment of principal and interest on the underlying mortgages by the federal housing agencies, Fannie Mae, Freddie Mac, or Ginnie Mae) the Fed also announced a doubling of its planned investment in the debt of the GSEs to $\$ 200$ billion. However, much of this debt is short to medium term (2 to 5 years), with Fannie's new 2-year benchmark note offering yields about 60bp above comparable Treasuries.

${ }^{31}$ One consequence is a further blow to the future commercial viability of Fannie Mae and Freddie Mac. Investors in mortgage-backed securities and long-term Treasuries also will be harmed by any temporary rate distortion which massive market support for long fixed-rate securities by the Fed may accomplish. At best, therefore, this Fed program will be ineffective as experience with sterilized intervention in exchange markets may suggest. The Federal Reserve's March 12, 2009 flow of funds release indicates that "Rest of 
the World" disinvested in \$1.0 trillion of “Agency and GSE-backed Securities” at an annual rate in the fourth quarter of 2008. This event indicates that, for liquid portfolio assets, large changes in positions by some may have little effect on price and yield for all.

${ }^{32} \mathrm{http} / / / \mathrm{www}$. federalreserve.gov/newsevents/press/monetary/20090318a.htm .

33 http://www.federalreserve.gov/newsevents/press/monetary/20090323b.htm .

${ }^{34}$ The speculation was that the special assessment could drop to 6bp factoring in a reduction from 20bp to 10bp if Congress enacts the $\$ 100$ billion line of credit and there is a $4 \mathrm{bp}$ further reduction on account of guarantee fees under the TLGP (described in Section III.D of this study) being transferred to the Deposit Insurance Fund (DIF) of the FDIC.

${ }^{35}$ On March 24, 2008, the Federal Reserve Bank of New York announced that it had agreed to lend \$29 billion in connection with the acquisition of Bear Stearns by JPMorgan Chase using the authority granted by Section 13(3) of the Federal Reserve Act. The loan, with an initial maturity of 10 years renewable by the New York Fed, was made at the primary credit rate, then 2.5 percent, which fluctuates with the Fed's discount rate. It is senior to $\$ 1$ billion of financing provided by a note from JPMorgan Chase at a floating rate of initially $7 \%$. The loan and subordinated note are extended against a portfolio of assets, marked to market by Bear Stearns 10 days earlier, that was transferred to a Delaware LLC, Maiden Lane, an entity created for that sole purpose by the New York Fed. BlackRock Financial Management has been retained by the New York Fed to manage and liquidate the assets, with any funds remaining from the liquidation of the assets after satisfying all other claims paid to the New York Fed. The Bear Stearns takeover also provides evidence of extreme market imperfection in a severe crisis that can make valuations arbitrary. JPMorgan Chase had announced on May 16, 2008, that it was offering \$236 million, or about \$2 worth of its own stock per share of Bear Stearns; but on March 24 it raised that offer fivefold to $\$ 10$ a share or $\$ 1.2$ billion. Ten days earlier, on March 14, 2008, Bear Stearns had been valued at \$3.5 billion, or \$30 per share at the close.

${ }^{36}$ Hence, the first application of the systemic-risk exception by the FDIC came on October 14, 2008. On that date the Fed announced its recommendation to the Secretary of the Treasury to invoke the systemic risk exception to the Federal Deposit Insurance Act, enabling the FDIC to provide the TLGP guarantees. ${ }^{37}$ Use of the systemic-risk exception requires the approval of (i) two thirds of the members of the FDIC's Board, (ii) two thirds of the members of the Board of Governors of the Federal Reserve System, and (iii) the Secretary of the U.S. Treasury who must first consult with (iv) the President.

${ }^{38}$ The link is to http://timeline.stlouisfed.org/pdf/CrisisTimeline.pdf , a timeline maintained by the Federal Reserve Bank of St. Louis.

39 At the beginning of September 2008, when crude oil prices were around \$110 per barrel, a noted Chief Economist of an IFI assessed the near-term outlook in a published interview as follows: "If the price of oil stabilizes, I believe we can weather the financial crisis at limited cost in terms of real activity. And if, for example, the price of oil returned toward $\$ 100$ - not a crazy scenario, as few of us understand how it got much above $\$ 100$ in the first place - then inflation pressure would subside rapidly and I would be even more optimistic." Similar faith in a soft landing was expressed in a summer 2008 publication by the research arm of a major accounting firm. While predicting a U.S. recession, it gave five reasons for optimism: 1. Unemployment claims will remain low. 2. Export growth is booming, 3. Inventories are tight, 4. Tech investment outlook remains positive, 5. Government will continue to spend. Advising natural healing, it noted that "the biggest risk of any recession is the ... efforts of government to try to 'do something' to stop recession.” A noted U.S. economist with Federal Reserve, IFI, academic, and hedge fund management experience, speaking at an August 8, 2008 conference in Chile, did not see the U.S. economy in recession but predicted that, if it were, it would recover by the fourth quarter of 2008. He also predicted that oil prices would stabilize at $\$ 90$ by yearend 2008. In actuality, U.S. real GDP declined at an annual rate of over $6 \%$ in the fourth quarter of 2008 and the price of light crude ended at about $\$ 45$ that year, being far from stable. An opinion piece published in a major financial newspaper on August 29, 2008 carried the title "Inflation is a Clear and Present Danger," but the seasonally adjusted CPI-U declined at an annual rate of $12.4 \%$ over the three months from September to December 2008. A Nobel-Prize-winning economist articulated what applied to the vast majority of the profession (including me) and to U.S. economic and financial analysts everywhere when he was quick to admit on October 7, 2008, "to having greatly underestimated the severity of the current crisis." One of his colleagues at the same university still remained blithely unconcerned about the economic outlook, proclaiming in an October 10 editorial that we're in a financial crisis, not in an economic crisis and, so, if you are not employed in the financial 
industry, don't worry. Because this lack of foresight was so common, it would be unfair and distracting to pick out particular names. Those who need to know who happened to get something right about the nearterm forecast, and for what reason other than luck and multiple shooting, may wish to consult an article by Chris Giles on "The Vision Thing" that was published in the Financial Times on November 25, 2008.

${ }^{40}$ For still highly incomplete evaluations see GAO (2008; 2009a, pp. 49-59, 63), CBO (2009), COP (2009), and Elliott (2009).

${ }^{41}$ Most of the business of IndyMac Federal was acquired by OneWest Bank Group LLC on March 19, 2009, meaning that the FDIC was in possession for roughly 8 months before the institution it had seized was cleaned up and returned to the private sector. 